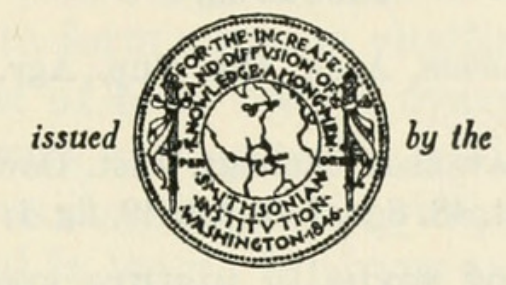

SMITHSONIAN INSTITUTION

U. S. NATIONAL MUSEUM

\title{
THE HELMINTH PARASITES OF BIRDS, III : DICROCOELIID TREMATODES FROM NORTH AMERICAN BIRDS
}

\author{
By J. Fred Denton and Elon E. Byrd
}

During the past several years we have examined, for helminth parasites, more than 700 specimens of wild birds, which represent 14 orders, 40 families, and 134 species. Although the avian hosts came from various localities throughout the southeastern section of the United States, the greater concentrations were collected from State College, Miss.; Athens and Augusta, Ga.; Highlands, N. C.; Reelfoot Lake, Tenn.; Eagle Lake and Houston, Tex.; and Mountain Lake, Va.

In the present paper only those trematodes belonging to the subfamily Dicrocoeliinae Looss, 1899, that were studied by us personally are considered in detail. We collected the greater part of the material included in this study, although we have been fortunate in obtaining specimens of several of the species from other investigators. ${ }^{1}$

1 For the loan of specimens of several species from outside the area covered the writers wish to thank Dr. Paul D. Harwood for material from Tennessee, Dr. Donald V. Moore for material from Texas, Dr. Robert Rausch for specimens from Ohio and Michigan, and Dr. F. G. Wallace for specimens of species collected by Ishii in Minnesota.

The senior author expresses his appreciation to Prof. Asa C. Chandler, Rice Institute, Houston, Tex., under whose direction this study was begun, for many valuable aids and suggestions. The junior author acknowledges his indebtedness to the Graduate School, University of Georgia, Athens, Ga.; the University Center, Atlanta, Ga.; the Mountain Lake Biological Station, Mountain Lake, Va.; and The Minnie D. Warren Fellowship, Highlands Museum and Biological Laboratory, Highlands, N. C., for financial assistance in making this study possible. 


\section{Genus LYPEROSOMUM Looss, 1899}

LYPEROSOMUM OSWALDOI (Travassos, 1919)

Figure 35, $a-c$

Oswaldoia oswaldoi Travassos, Arch. Esc. Sup. Agr., vol. 3 (1919), pp. 15-17, fig. 6, 1920.

Lyperosomum oswaldoi Travassos, Monogr. Inst. Oswaldo Cruz, No. 2, pp. 141145, est. 47, figs. $1-5$; est. 48, figs. 1-5 ; est. 49, fig. 1, 1944.

Description.-Body of sexually mature specimens (fig. 35, $a, b$ ) elongated, slender, 4.35 to $10.65 \mathrm{~mm}$. long by 0.39 to $0.77 \mathrm{~mm}$. wide in testicular zone, semitransparent, slightly flattened dorsoventrally; preacetabular region short, narrowing abruptly to blunt anterior extremity; postacetabular segment extremely elongated, gradually tapering to rounded posterior end. Cuticle aspinose, with fine transverse striations and small retractile sensory papillae, which are usually more clearly visible along margins of body of living specimens. Oral sucker subterminal, 0.15 to $0.30 \mathrm{~mm}$. long by 0.16 to $0.31 \mathrm{~mm}$. wide, preceded dorsally by a short liplike projection. Acetabulum large, 0.37 to $0.66 \mathrm{~mm}$. in diameter, strongly muscular, cup-shaped with a deep lumen (fig. $35, b$ ), located within anterior seventh of body. Ratio of width of oral sucker to acetabulum about $1: 2$. Pharynx globular, relatively small, 0.06 to $0.15 \mathrm{~mm}$. in diameter. Length of esophagus approximately equal to diameter of pharynx. Ceca slender, slightly sinuous, unequal in length, terminating one-half to two-thirds distance from vitellaria to caudal extremity of body. Excretory pore terminal. Excretory vesicle thin-walled, tubular, extending anteriad almost to seminal receptacle, where it receives a common collecting tubule from each side of body. Common collecting tubules passing anteriad laterally to gonads to zone of posterior third of acetabulum, where each branches into an anterior and posterior main collecting tubule. Genital pore approximately median, at level of posterior limits of pharynx. Testes round to oval, 0.11 to $0.30 \mathrm{~mm}$. long by 0.13 to 0.36 $\mathrm{mm}$. wide, oblique in position, located close behind acetabulum, in anterior fourth of body. Anterior testis may be on right or left side of body midline. Cirrus sac club-shaped, small, 0.07 to $0.19 \mathrm{~mm}$. long by 0.04 to $0.10 \mathrm{~mm}$. wide, usually lying entirely in front of acetabulum, containing convoluted seminal vesicle, ejaculatory duct surrounded by prostatic gland cells and eversible cirrus. Ovary round to transversely oval, 0.07 to $0.27 \mathrm{~mm}$. long by 0.13 to $0.31 \mathrm{~mm}$. wide, situated from 0.10 to $0.35 \mathrm{~mm}$. behind caudal testis and on same side of body as that organ. Seminal receptacle globular, located just posterior to ovary. Mehlis' gland at posteromedial margin of seminal receptacle. Vitellaria lateral in position, composed of numerous small follicles, beginning anteriorly at a level within zone of anterior testis and extending posteriorly for a distance of 1.85 to $4.34 \mathrm{~mm}$., terminating 
at a level approximately midway between acetabulum and posterior end of body. Vitelline ducts emerging from yolk glands at a level one-third to one-half their length from anterior limits, uniting in median plane of body to form common vitelline duct. Uterus greatly convoluted, filling most of body behind ovary, passing anteriorly on right or left side of ovary and posterior testis, between testes, dorsal to acetabulum and cirrus sac, terminating in a weakly muscular metraterm. Metraterm equal in length in cirrus sac. Ova numerous, dark brown when mature, measuring $26 \mu$ to $33 \mu$ long by $18 \mu$ to $22 \mu$ wide. Ciliated miracidium possessing a stylet and two large oval, oppositely situated vesicles which are filled with refractile granules.

Additional hosts.- Toxostoma rufum (Linnaeus) and Cyanocitta cristata (Linnaeus).

Habitat.-Liver and gall bladder.

Localities.-Georgia : Augusta and Athens; Mississippr: State College; Texas: Houston and Eagle Lake.

Material.-Specimens No. 36749, 36750, 36751, and 36794 have been deposited in the helminthological collection of the United States National Museum.

Remarks.-Lyperosomum oswaldo $i$ is described here from numerous specimens from the liver and gall bladder of the brown thrasher, Toxostoma rufum, and two specimens from the gall bladder of the blue jay, Cyanocitta cristata, from the southern United States. The parasite is common in the brown thrasher, being recorded from 20 (48.8 percent) of 41 specimens of this species examined to date. The blue jay, on the other hand, must be considered as a rare or accidental host for the species, since only a single specimen ( 3.8 percent) of 26 birds proved to carry the form in its gall bladder. However, the parasite in the blue jay was normal in every way and was fully gravid. The specimens from the blue jay were indistinguishable from those in the brown thrasher.

Lyperosomum oswaldoi apparently represents the New World counterpart of $L$. longicauda (Rudolphi, 1809), from birds of the Old World. In Europe L. longicauda appears to be confined to birds of the family Corvidae (crows and jays), while $L$. oswaldoi has been recorded from birds of the families Thraupidae (tanagers), Icteridae (blackbirds), Phasianidae (partridges), and Fringillidae (sparrows) in South America and from species of Mimidae (thrashers) and Corvidae in North America (present paper). The two species, L. longicauda and $L$. oswaldoi, have the same general body appearance and internal organization but show certain minor differences. The body and internal organs, with the exception of the ova which are considerably larger, are smaller in $L$. oswaldoi than in L. longicauda. Very probably $L$. oswaldoi will fall as a synonym of $L$. longicauda (sensu 
stricto) when the latter is more completely described. At the present time, however, we feel justified in regarding the two forms as distinct.

While comparing $L$. oswaldo $i$ with other closely related forms of the genus Lyperosomum, it has been made clear to us that L. skrjabini (Solowiow, 1911), described from the same hosts as $L$. longicauda, must be considered a direct synonym of the latter. Further, it is our opinion that $L$. urocissae Yamaguti, 1939, is a synonym of $L$. oswaldoi.

\section{Genus LUTZTREMA Travassos, 1941}

\section{LUTZTREMA MONENTERON (Price and McIntosh, 1935)}

\section{Figure 34, $a-d$}

Lyperosomum monenteron Price and McIntosh, Proc. Helm. Soc. Washington, vol. 2, pp. 63-64, fig. 12, 1935.

Lutztrema monenteron Travassos, Mem. Inst. Oswaldo Cruz, vol. 36, pp. 336-338, 1941.

The material in the present collection agrees very closely with that described by Price and McIntosh (1935). The present study has brought out several features that might be of aid in recognizing the species as being separate and distinct from its closest relative, $L$. obliquum (Travassos, 1917). These features only will be considered. The body of the relaxed specimen (fig. 34, $a$ ) is widest in the region of the anterior testis; it tapers gradually from this point toward both ends. Although aspinose, the cuticle usually exhibits fine transverse ridges over most of the body while small, conical, retractile sensory papillae appear on the surface of the oral sucker and along the margins of the preacetabular region of the body; these papillae are readily observed on living worms. The acetabulum (fig. $34, b$ ) is strongly muscular and cup-shaped with a deep lumen; it is usually set in the bottom of an acetabular depression. The ratio of the width of the oral sucker to acetabulum varies from $1: 1.65$ to $1: 2$. The cecum passes between the testes and between the posterior testis and ovary, and without exception terminates well in advance of the posterior end of the body, usually terminating anywhere from just posterior to the vitellaria to a point about one-third the distance from the vitellaria to the posterior end of the body. The common collecting tubules of the excretory system arise from the anterior end of the excretory vesicle and pass anterolaterally to a level midway between the testicular zones where they divide into anterior and posterior main collecting tubules. Each of the main collecting tubules gives rise to three short accessory tubules, each of which branches into two capillaries. Each capillary tubule terminates in a single flame cell, thus establishing a 
$2[(2+2+2)+(2+2+2)]$ flame cell pattern. The vasa efferentia arise from the dorsomedial surfaces of the testes and unite midway between the anterior testis and acetabulum to form a long vas deferens,
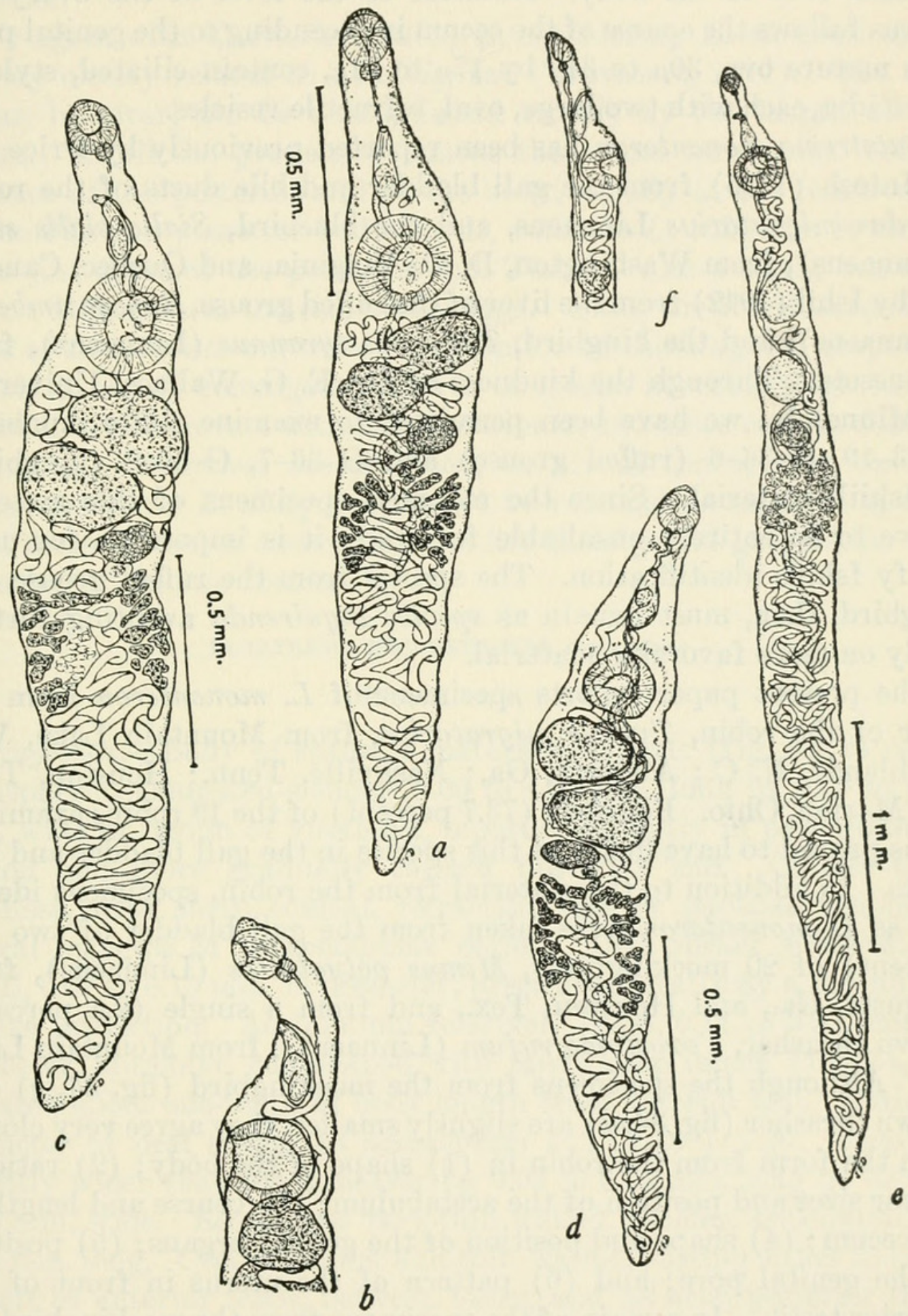

Figure 34.- a, Lutztrema monenteron (Price and McIntosh, 1935) from the gall bladder of Turdus migratorius, ventral view; $b$, optical sagittal section of anterior end of Lutztrema monenteron from Turdus migratorius, showing ventral flexure of anterior end and the position and deep lumen of the acetabulum; c, Lutztrema monenteron from the gall bladder of Mimus polyglottos, ventral view; $d$, Lutztrema monenteron from the gall bladder of Toxostoma rufum, ventral view, specimen slightly shrunken; e, Lutztrema microstomum, new species, from the gall bladder of $C$ yanocitta cristata, ventral view; $f$, optical sagittal section of anterior end of Lutztrema microstomum from Cyanocitta cristata, showing position of suckers and deep lumen of acetabulum. 
which parallels the course of the cecum to the cirrus sac. The transversely oval testes frequently show a distinct indentation of their lateral margins. The number of vitelline follicles varies from 8 to 14 on each side of the body. Anterior to the level of the ovary the uterus follows the course of the cecum in ascending to the genital pore. The mature ova, $30 \mu$ to $34 \mu$ by $17 \mu$ to $21 \mu$, contain ciliated, styleted miracidia, each with two large, oval, refractile vesicles.

Lutatrema monenteron has been reported previously by Price and McIntosh (1935) from the gall bladder and bile ducts of the robin, Turdus migratorius Linnaeus, and the bluebird, Sialia sialis sialis (Linnaeus), from Washington, D. C., Virginia, and Quebec, Canada, and by Ishii (1942) from the liver of the ruffed grouse, Bonasa umbellus (Linnaeus), and the kingbird, Tyrannus tyrannus (Linnaeus), from Minnesota. Through the kindness of Dr. E. G. Wallace, University of Minnesota, we have been permitted to examine slides numbered G-33-19, G-36-6 (ruffed grouse) and G-36-7, G-36-8 (kingbird) of Ishii's material. Since the mounted specimens' of this material prove to be entirely unsuitable for study it is impossible for us to verify Ishii's identification. The species from the ruffed grouse and kingbird, then, must remain as species inquirenda awaiting further study on more favorable material.

The present paper reports specimens of $L$. monenteron from the liver of the robin, Turdus migratorius, from Mountain Lake, Va.; Highlands, N. C.; Augusta, Ga.; Nashville, Tenn.; Houston, Tex.; and Marion, Ohio. Fourteen (73.7 percent) of the 19 robins examined by us proved to have flukes of this species in the gall bladder and bile ducts. In addition to the material from the robin, specimens identified as $L$. monenteron were taken from the gall bladder of two (10 percent) of 20 mockingbirds, Mimus polyglottos (Linnaeus), from Augusta, Ga., and Houston, Tex., and from a single (2.4 percent) brown thrasher, Toxostoma rufum (Linnaeus), from Mountain Lake, Va. Although the specimens from the mockingbird (fig. 34,c) and brown thrasher (fig. 34, $d$ ) are slightly smaller, they agree very closely with the form from the robin in (1) shape of the body; (2) ratio of sucker sizes and position of the acetabulum; (3) course and length of the cecum; (4) shape and position of the genital organs; (5) position of the genital pore; and (6) pattern of the uterus in front of the anterior testis. In certain of the specimens from the mockingbird the ova measure as much as $39 \mu$ in length, while in other specimens from the same host they fall within the range given for the ova from the robin material. Further evidence that the worm from the mockingbird is identical with the form in the robin is obtained through lifehistory studies; the larval stages of the two forms are indistinguishable (unpublished data). 
Specimens No. 36759 and 36760 from the robin, No. 37114 from the mockingbird, and No. 37113 from the brown thrasher have been deposited in the helminthological collection of the United States National Museum.

We agree with Travassos (1944) in considering $L$. monenteron to be very closely related to $L$. obliquum (Travassos, 1917). The two forms, however, can be distinguished readily by the length of the cecum. In all the present specimens the cecum terminates well in advance of the posterior end of the body, usually at the junction of the middle and posterior body thirds, while in L. obliquum it terminates just short of the posterior end. There is also a slight but consistent difference in the size of the eggs. Since the North American hosts' of $L$. monenteron, with the exception of the kingbird (reported by Ishii), are all nonmigratory birds or species in which migration is confined to movements within the continent, and since certain definite anatomical differences are observed, we are of the opinion that $L$. monenteron and $L$. obliquum should be retained as separate species until more is known concerning the life history and geographic distribution of the two forms.

\section{LUTZTREMA MICROSTOMUM, new species}

\section{Figure 34, $e, f$}

Diagnosis.-Body of sexually mature specimens (fig. 34, e) semitransparent, elongated-slender, 3.00 to $4.95 \mathrm{~mm}$. long by 0.19 to 0.46 $\mathrm{mm}$. wide in region of vitellaria, tapering abruptly in preacetabular region and more gradually toward posterior end. Cuticle thin, aspinose, with small conical, retractile, sensory papillae visible on lateral margins of preacetabular region. Oral sucker subterminal, small, 0.07 to $0.13 \mathrm{~mm}$. in diameter, preceded dorsally by a prominent liplike projection. Acetabulum relatively large, 0.14 to $0.23 \mathrm{~mm}$. in diameter, muscular, cup-shaped with fairly deep lumen (fig. $34, f$ ), situated about one-tenth of body length from anterior end. Ratio of diameter of oral sucker to acetabulum $1: 1.75$ to $1: 2.80$. Pharynx slightly wider than long, measuring 0.03 to $0.05 \mathrm{~mm}$. long by 0.03 to $0.06 \mathrm{~mm}$. wide. Esophagus very thin-walled, slender, approximately $0.14 \mathrm{~mm}$. long. Cecum slender and thin-walled, passing either to right or left of anterior testis, between testes, and between posterior testis and ovary, then continuing posteriorly in more or less wide undulations to near body middle, where it terminates. Excretory pore terminal. Excretory vesicle thin-walled, narrow, tubular, extending anteriad to level of anterior limits of vitellaria, where it receives two common collecting tubules. Each common collecting tubule receives an anterior and posterior main collecting tubule at level of intertesticular zone. Genital pore median, located approximately midway 
between suckers. Testes rounded to transversely oval, 0.11 to 0.26 $\mathrm{mm}$. long by 0.12 to $0.31 \mathrm{~mm}$. wide, situated slightly obliquely in anterior third of body with zone of posterior testes entirely behind that of anterior, a relative position retained even in greatly contracted specimens. Vasa efferentia arising from dorsomedial surfaces of testes, uniting just in front of anterior testis to form a long vas deferens. Cirrus sac elongated-pyriform, 0.12 to $0.16 \mathrm{~mm}$. long by 0.06 to $0.07 \mathrm{~mm}$. wide, containing a coiled seminal vesicle, ejaculatory duct surrounded by prostatic gland cells and a cirrus, which is usually observed to be partly everted in preserved specimens. Cirrus sac usually contiguous with anterior margin of acetabulum. Ovary transversely oval, 0.08 to $0.15 \mathrm{~mm}$. long by 0.08 to $0.18 \mathrm{~mm}$. wide, submedial in position close behind posterior testis. Seminal receptacle large, globular, posterior to caudal margin of ovary. Mehlis' gland located immediately posterior to seminal receptacle. Laurer's canal opening to outside dorsally to posterior third of ovary. Vitellaria composed of 8 to 15 large, oval follicles on each side of body, tending to fuse in median line anteriorly, located just posterior to seminal receptacle. Vitelline ducts arising from anterior vitelline follicles and uniting medianly to form common yolk reservoir. Uterus much convoluted, filling most of body posterior to ovary, usually following course of cecum in ascending, sometimes leaving cecum to ascend on same side of ovary and posterior testis. Uterus describing several, usually 3 to 6 , lateral loops between anterior testis and acetabulum before ascending to genital pore. Metraterm weakly muscular, equal in length to cirrus sac. Mature ova dark brown, $29 \mu$ to $35 \mu$ long by $19 \mu$ to $24 \mu$ wide, fully embryonated when oviposited.

Host.-Cyanocitta cristata (Linnaeus).

Habitat.-Liver and gall bladder.

Localities.-Texas : Houston (type); Georgia : Augusta ; and North Carolina : Highlands.

Molluscan hosts.-Bulimulus alternatus mariae (Albers), Deroceras reticulatum (Müller), and Deroceras laeve (Müller).

Type specimen.-U. S. N. M. Helm. Coll. No. 36761. Additional specimen, No. 36769.

Remarks.-Lutztrema microstomum is recorded only from the blue jay Cyanocitta cristata. Seven ( 27 percent) of the 26 specimens of this host examined harbored from 1 to over 200 worms (average 42 per bird). Lutztrema microstomum can be separated from L. monenteron, the only other member of the genus thus far encountered from birds in the United States, by its smaller and much narrower body, its relatively larger and more anteriorly situated acetabulum, its relatively shorter cecum, its more tandem testes, the greater distance between the acetabulum and testes, and the pattern of the uterus in front of the anterior testis. 
Genus BRACHYLECITHUM Strom, 1940

BRACHYLECITHUM RARUM (Travassos, 1917)

Figure 35, $d, e$

Lyperosomum rarum Travassos, First Conf. Soc. Sud. Amer. Hig., pp. 738, 741-742, fig. 4 (1916), 1917.

Brachylecithum rarum Sтвом, Parasitol, Sborn. Zool. Inst. Akad. Nauk U.S.S.R., vol. 8 , p. $183,1940$.

Olssoniella rara Travassos, Monogr. Inst. Oswaldo Cruz, No. 2, pp. 217-218, est. 84, figs. 1-3 ; est. 85, figs. 1-2, 1944.

Description.-Body of mature specimens large and robust, 4.50 to $6.90 \mathrm{~mm}$. long by 0.30 to $0.49 \mathrm{~mm}$. wide between acetabulum and vitellaria, slightly flattened dorsoventrally, with almost parallel sides' and rounded ends. Cuticle aspinose, but with prominent fingerlike tuberculations irregularly distributed over body except for region anterior to genital pore. Oral sucker subterminal in position, large and muscular, 0.28 to $0.38 \mathrm{~mm}$. long by 0.28 to $0.31 \mathrm{~mm}$. wide. Acetabulum weakly muscular, 0.29 to $0.35 \mathrm{~mm}$. long by 0.29 to $0.41 \mathrm{~mm}$. wide, with shallow, saucerlike lumen in living or relaxed specimens, or with center protruded (fig. 35, e) so as to eliminate lumen in most fixed specimens, located in anterior sixth of body. Ratio of width of oral sucker to acetabulum $1: 1.05$ to $1: 1.34$. Prepharynx absent. Pharynx muscular, globular, longer than wide, 0.09 to $0.11 \mathrm{~mm}$. long by 0.08 to 0.10 $\mathrm{mm}$. wide. Esophagus slender, straight to slightly wavy, bifurcating from one-half to three-fourths of distance from oral sucker to acetabulum. Ceca of medium width, fairly thick-walled, straight to slightly wavy, passing dorsal to acetabulum, dorsal to lateral margins of gonads and dorsal to vitellaria, terminating unevenly near body middle, with ends forming distended pouches. Excretory pore terminal. Excretory vesicle thin-walled, tubular, extending anteriad to near anterior limits of vitellaria. Genital pore medium, ventral to intestinal bifurcation. Testes round to oval, equal in size, 0.17 to 0.32 $\mathrm{mm}$. in diameter, situated in body midline, with one directly behind the other. Anterior testis separated from acetabulum by three to six transverse loops of uterus; posterior testis usually separated from anterior one by a single dorsoventral loop of uterus. Vasa efferentia arising from dorsomedial surfaces' of testes and uniting just posterior to caudal margin of acetabulum to form an almost straight vas deferens. Cirrus sac elongated-pyriform, 0.18 to $0.25 \mathrm{~mm}$. long by 0.07 to $0.10 \mathrm{~mm}$. wide, containing a coiled seminal vesicle, ejaculatory duct surrounded by prostatic gland cells and eversible cirrus. One-third to one-half of cirrus sac lies dorsally to acetabulum. Ovary transversely oval in shape, 0.11 to $0.18 \mathrm{~mm}$. long by 0.14 to $0.21 \mathrm{~mm}$. wide, situated in middle of body and separated from posterior testis by one to 
four transverse loops of uterus. Seminal receptacle small, globular, situated entirely posterior to ovary. Mehlis' gland diffuse, located
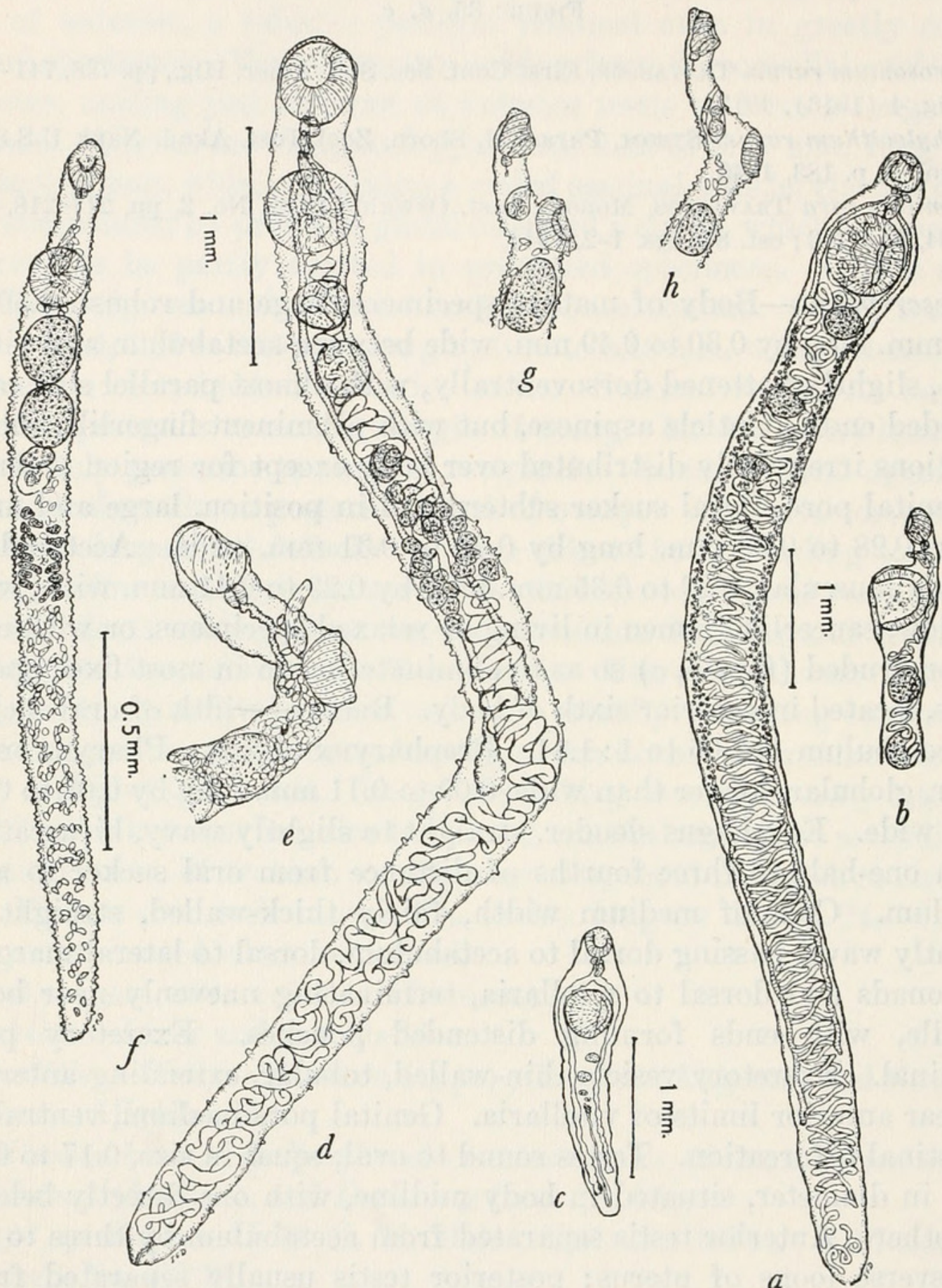

FigUre 35.-a, Adult Lyperosomum oswaldoi (Travassos, 1919) from the gall bladder of Toxostoma rufum, ventral view; $b$, optical sagittal section of anterior end of Lyperosomum oswaldoi from Toxostoma rufum, showing position and lumen of acetabulum; $c$, very young specimen of Lyperosomum oswaldoi removed from the gall bladder of Toxostoma rufum, showing similarity in shape and arrangement of organs to that of adult; $d$, Brachylecithum rarum (Travassos, 1917) from the liver of Pipilo erythrophthalmus, ventral view; e, lateral view of anterior end of Brachylecithum rarum from Pipilo erythrophthalmus, showing position of suckers and protruding center of acetabulum; $f$, Brachylecithum tuberculatum, new species, from the liver of Wilsonia canadensis, ventral view; $g, h$, lateral views of anterior ends of Brachylecithum tuberculatum from Wilsonia canadensis, showing acetabulum with shallow lumen and with center protruded. 
posteromedial to seminal receptacle. Laurer's canal not observed. Vitellaria consisting of 7 to 14 large oval to rounded, discrete follicles on each side of body, tending to meet ventrally at anterior limits and eccupying zone immediately posterior to Mehlis' gland. Uterus much convoluted, filling most of body posterior to vitellaria, then passing forward ventrally to vitellaria and ovary (in two specimens the uterus passes dorsally to the ovary) by undulating course, dorsally between ovary and posterior testis, dorsally to both testes and acetabulum to genital pore. Mature ova dark brown, fully embryonated when oviposited, $44 \mu$ to $57 \mu$ long by $23 \mu$ to $33 \mu$ wide.

Additional host.-Pipilo erythrophthalmus (Linnaeus).

Habitat.-Liver and bile ducts.

Localities.-Virginia: Mountain Lake; North Carolina: Highlands.

Material.-Two specimens have been deposited in the helminthological collection of the U. S. National Museum, No. 37115.

Remarks.-Brachylecithum rarum is described here from 25 mature specimens from the liver of the red-eyed towhee, Pipilo erythrophthalmus, from Mountain Lake, Va., and Highlands, N. C. The material in the present collection agrees very closely with that described by Travassos $(1917,1944)$ except for the size of the pharynx, which is slightly larger in our material.

\section{BRACHYLECITHUM TUBERCULATUM, new species}

\section{Figure $35, f-h$}

Diagnosis.-Body of mature specimen elongated-cylindrical, with rounded anterior and tapering posterior ends, 1.93 to $3.43 \mathrm{~mm}$. long by 0.17 to $0.20 \mathrm{~mm}$. wide in region of testes. Cuticle aspinose, with numerous close-set conical tuberculations irregularly distributed over body except in region of oral sucker Oral sucker subterminal, weakly muscular, elongated-oval in shape, 0.11 to $0.18 \mathrm{~mm}$. long by 0.10 to 0.13 $\mathrm{mm}$. wide, with oral opening directed ventrally. Acetabulum weakly muscular, 012 to $0.15 \mathrm{~mm}$. in diameter, with shallow saucerlike lumen (fig. 35, g) in living and contracted specimens, or with center protruded (fig. $35, h$ ), obliterating lumen in most fixed specimens, located in anterior fifth of body. Ratio of width of oral sucker to acetabulum $1: 1.18$ to $1: 1.37$. Prepharynx absent. Pharynx muscular, longer than wide, 0.03 to $0.05 \mathrm{~mm}$. long by 0.03 to $0.04 \mathrm{~mm}$. wide. Esophagus very thin-walled, slender, straight to slightly wavy, bifurcating from one-half to two-thirds distance from oral sucker to acetabulum. Ceca narrow, very thin-walled (visible only in sectioned specimens), slightly undulating, passing dorsally to acetabulum, dorsally to margins of testes and dorsally to vitellaria, terminating unevenly just posterior to 
last follicles of vitellaria. Excretory pore terminal. Genital pore median, one-half to two-thirds distance from oral sucker to acetabulum, ventral to or slightly anterior to intestinal bifurcation. Testes round to elongated-oval, equal in size, measuring 0.12 to $0.28 \mathrm{~mm}$. long by 0.08 to $0.16 \mathrm{~mm}$. wide, situated one directly behind other, occupying most of width of body. Anterior testis touching acetabulum or separated from it by one or two loops of uterus; posterior testis contiguous with anterior testis. Cirrus sac elongated-pyriform, 0.13 to $0.15 \mathrm{~mm}$. long by 0.05 to $0.06 \mathrm{~mm}$. wide, containing coiled seminal vesicle, ejaculatory duct surrounded by prostatic gland cells and eversible cirrus, from one-third to one-half its length lying dorsally to acetabulum. Ovary round to oval in shape, smaller than testes, 0.05 to $0.10 \mathrm{~mm}$. long by 0.07 to $0.10 \mathrm{~mm}$. wide, located on midline immediately behind posterior testis or separated from that organ by one to three loops of uterus. Seminal receptacle larger than ovary, immediately posterior to ovary. Vitellaria consisting of 8 to 10 medium-sized, ovoid follicles on each side of body, occupying zone posterior to seminal receptacle. Uterus much convoluted, filling body posterior to vitellaria, passing anteriorly between and ventrally to vitellaria, ventrally to middle or to one or other margin of ovary, dorsally between ovary and posterior testis, dorsally to both testes and acetabulum, then following straight or slightly undulating course to genital pore. Metraterm weakly muscular, equal in length to cirrus sac. Mature ova very dark brown, embryonated when oviposited, $36 \mu$ to $40 \mu$ long by $21 \mu$ to $27 \mu$ wide.

Host.-Wilsonia canadensis (Linnaeus).

Habitat.-Liver.

Locality.-VIRGINIA: Mountain Lake.

Type specimen.-U.S.N.M. Helm. Coll. No. 37117.

Remarks.-Brachylecithum tuberculatum is described from eight specimens obtained from the liver of two of six Canada warblers, Wilsonia canadensis, from Mountain Lake, Va. The species shows a closer affinity to $B$. rarum (Travassos, 1917) than to the other members of the genus in that its body is covered with tuberculations. As compared with this large robust species, $B$. tuberculatum is a small delicate form that possesses differently shaped and more numerous tuberculations, inconspicuous ceca, proportionately larger testes, a different type of vitellaria and a uterus which follows a different course in ascending to the genital pore.

\section{BRACHYLECITHUM NANUM, new species}

Figure $36, a-d$

Diagnosis.-Body much elongated-cylindrical, with weakly developed musculature and showing a tendency to be serpentine; it measures 1.85 to $3.39 \mathrm{~mm}$. long by 0.10 to $0,26 \mathrm{~mm}$. wide, widest in 
region between acetabulum and vitellaria. Cuticle thin, aspinose, smooth except for small, conical, sensory papillae along margins of suckers and on lateral margins of body in some specimens. Oral sucker subterminal to a small liplike projection, weakly muscular, usually elongate oval in shape, measuring 0.07 to $0.16 \mathrm{~mm}$. long by 0.08 to $0.15 \mathrm{~mm}$. wide. Acetabulum somewhat protrusible, weakly muscular, slightly lemon shaped in frontal view but without prominent auricular appendages, with shallow, saucerlike lumen (fig. 36, c) in some specimens or with center protruded (fig. $36, b$ ) in others, obliterating lumen; located in anterior body fifth and measuring 0.10 to $0.18 \mathrm{~mm}$. long by 0.11 to $0.20 \mathrm{~mm}$. wide. Ratio of width of oral sucker to acetabulum $1: 1.0$ to $1: 1.4$. Prepharynx absent. Pharynx muscular, globular, longer than wide, 0.03 to $0.05 \mathrm{~mm}$. long by 0.03 to $0.04 \mathrm{~mm}$. wide. Esophagus very thin-walled, slender, straight to slightly wavy, relatively long, bifurcating from one-half to two-thirds of distance from oral sucker to acetabulum. Ceca thin-walled, slender, straight to slightly wavy, passing dorsally to acetabulum, dorsally to lateral margins of gonads, dorsally to vitellaria, terminating unevenly as slightly distended tubes from a short distance posterior to vitellaria to midway between vitellaria and posterior end of body. Excretory pore terminal. Genital pore median, ventral to intestinal bifurcation. Testes elongated-oval to kidney-shaped, approximately equal in size, 0.09 to $0.27 \mathrm{~mm}$. long by 0.07 to $0.19 \mathrm{~mm}$. wide, situated one directly behind other and occupying almost entire width of body at their levels; depending on state of constriction of body, anterior testis separated from acetabulum by one to four loops of uterus; posterior testis contiguous to anterior testis or separated from it by a single uterine loop. Cirrus sac elongated-pyriform, 0.12 to $0.16 \mathrm{~mm}$. long by 0.04 to $0.06 \mathrm{~mm}$. wide, containing coiled seminal vesicle, ejaculatory duct, and eversible cirrus, extending posteriorly far enough for one-third to one-half its length to lie dorsally to acetabulum. Ovary oval, 0.05 to $0.12 \mathrm{~mm}$. long by 0.06 to $0.16 \mathrm{~mm}$. wide, situated near middle of body and separated from posterior testis by one to three uterine loops. Seminal receptacle small, globular, situated entirely posterior to ovary, near either margin of body. Mehlis' gland diffuse, located posteromedial to seminal receptacle. Laurer's canal opening on middorsal surface at caudal level of seminal receptacle. Vitellaria consisting of 6 to 10 large oval to irregular follicles on each side of body (sometimes fusing together to form large irregular masses of yolk cells), occupying zone immediately posterior to Mehlis' gland. Uterus greatly convoluted with loops rather indistinct, filling body posterior to vitellaria, then passing anteriorly between and ventrally to vitellaria, ventrally to one margin of ovary, to dorsal side between ovary and posterior testis, dorsally to both testes and acetabulum to 


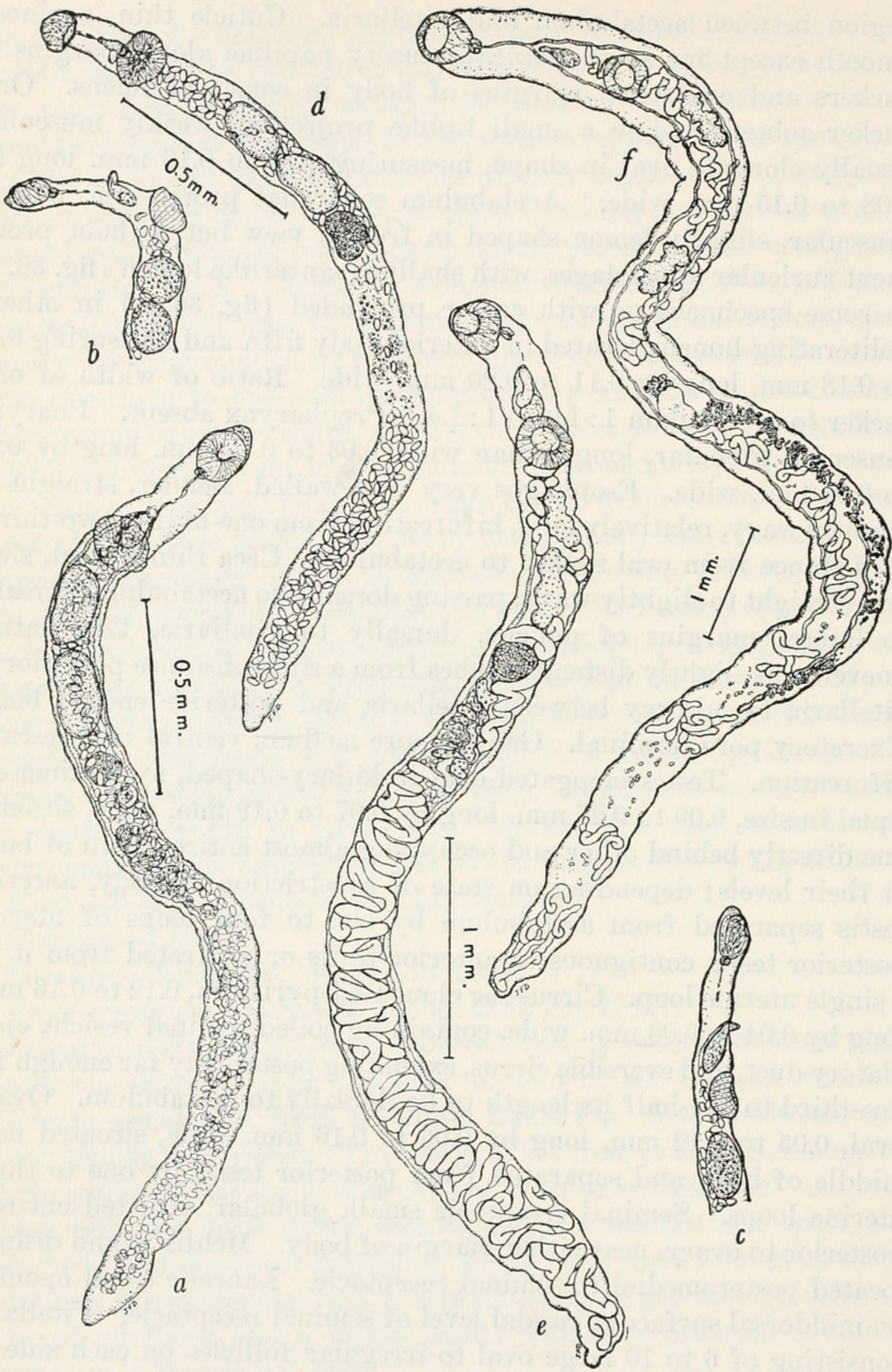

Figure 36.- a. Brachylecithum nanum, new species, from the liver of Pipilo erythrophthalmus, ventral view; $b, c$, lateral views of anterior ends of Brachylecithum nanum from Pipilo erythrophthalmus, showing acetabulum with center protruded and with shallow lumen; $d$, Brachylecithum nanum from the liver of Zonotrichia albicollis, ventral view; e, Brachylecithum gruis, new species, from the liver of Grus canadensis tabida, ventral view (drawing made from camera lucida sketches of parts of three worms); $f$, Athesmia heterolecithodes (Braun, 1899) from the liver of Gallinula chloropus cachinnans, dorsal view. 
genital pore. Mature ova dark brown, $38 \mu$ to $48 \mu$ long by $21 \mu$ to $28 \mu$ wide, fully embryonated when oviposited.

Hosts.-Pipilo erythrophthalmus (Linnaeus) (type) and Zonotrichia albicollis (Gmelin).

Habitat.-Liver.

Localities.-North Carolina : Highlands (type); Virginia : Mountain Lake; Georgia: Athens and Augusta; Texas: Houston.

Type specimen: U.S.N.M. Helm. Coll. No. 37116. Additional specimen, No. 36758, from the white-throated sparrow.

Remarks.-Brachylecithum nanum is described from specimens from the livers of 9 (27.3 percent) of 33 red-eyed towhees, Pipilo erythrophthalmus, collected at Highlands, N. C., and Mountain Lake, Va., and from 4 (12.9 percent) of 31 white-throated sparrows, Zonotrichia albicollis, collected in Georgia and Texas. Because of their delicate structure and the difficulty with which they are extracted, many specimens were broken during removal. Other specimens, because of a tendency to rotate a part of the body, are poor for detailed study. The species shows a close relationship to no less than five of the already described forms : B. filliforme (Skrjabin, 1913), B. megastoma (Johnston, 1917), B. vanellicolae (Layman, 1922), B. loossi (Layman, 1926), and $B$. asovi (Layman, 1926). Of these only B. filliforme is described and figured in sufficient details to permit comparison with $B$. nanum. From it $B$. nanum differs in being smaller and in having relatively larger suckers, relatively larger testes, and a much smaller cirrus sac. The type material of $B$. filliforme came from the gall bladder of a hawk, Circus cyaneus.

BRACHYLECITHUM GRUIS, new species

Figure $36, e$

Diagnosis.-Body thin and semitransparent, greatly elongated, tapering gradually at posterior end, measuring approximately 5.24 $\mathrm{mm}$. long by 0.26 to $0.30 \mathrm{~mm}$. wide at acetabulum. Cuticle without spines or other obvious markings. Oral sucker subterminal, weakly muscular, $0.25 \mathrm{~mm}$. long by $0.23 \mathrm{~mm}$. wide. Acetabulum weakly muscular, approximately equal in size to oral sucker, 0.18 to $0.28 \mathrm{~mm}$. in diameter, within anterior sixth of body. Pharynx globular, $0.09 \mathrm{~mm}$. in diameter. Esophagus narrow, thin-walled, about twice as long as pharynx, bifurcating approximately midway between suckers. Ceca slender, slightly wavy, passing laterally to gonads to terminate about two-thirds the distance from vitellaria to posterior end of body. Excretory pore terminal. Genital pore median at intestinal bifurcation. Testes distinctly lobed, approximately equal in size, 0.26 to $0.41 \mathrm{~mm}$. long by 0.14 to $0.19 \mathrm{~mm}$. wide: anterior testis separated from 
acetabulum by two or three lateral loops of uterus; posterior testis entirely behind anterior one. Cirrus sac elongated-oval, 0.15 to 0.27 $\mathrm{mm}$. long by 0.07 to $0.11 \mathrm{~mm}$. wide, containing much convoluted seminal vesicle, ejaculatory duct and eversible cirrus. Ovary oval, 0.13 to $0.24 \mathrm{~mm}$. long by 0.12 to $0.23 \mathrm{~mm}$. wide, slightly submedially in position. Seminal receptacle globular, dorsal to caudal margin of ovary. Vitellaria consisting of 10 to 12 large irregular follicles on each side of body, in anterior half of body, just caudal to seminal receptacle. Uterus greatly convoluted in descending and ascending, filling most of postovarial portion of body, then passing anteriorly to left of ovary and posterior testis and between testes to genital pore. Mature ova dark brown, $36 \mu$ to $42 \mu$ long by $22 \mu$ to $23 \mu$ wide.

Host.-Grus canadensis tabida (Peters).

Habitat.-Liver.

Locality.-Texas: Clodine.

Type material.-U. S. N. M. Helm. Coll. No. 36757.

Remarks.-Brachylecithum gruis is described from pieces of seven worms from the livers of two sandhill cranes, Grus canadensis tabida. These birds died of a limberneck disease occurring in wintering birds in the vicinity of Clodine, Tex., during January 1940. Only fragments of the worm were available for study, although one nearly complete worm is included in the collection.

Brachylecithum gruis has an elongated, serpentine body and suckers of approximately equal size, which, together with the elongated, distinctly lobed testes situated one entirely behind the other and a relatively large oval ovary, distinguish it from other species of the genus.

BRACHYLECITHUM SEIURICUM, new species

FIgURe 37, $a-f$

Diagnosis.-Body flattened dorsoventrally, elongated, 1.79 to 2.37 $\mathrm{mm}$. long by 0.18 to $0.29 \mathrm{~mm}$. wide in region between anterior testis and vitellaria, with almost parallel sides and rounded or slightly tapering extremities. Musculature of body weakly developed. Cuticle thin, aspinose, with fine transverse ridges. Small sensory papillae on margins of body in some specimens. Oral sucker subterminal to inconspicuous liplike protuberance, weakly muscular, 0.11 to $0.14 \mathrm{~mm}$. in diameter. Acetabulum weakly muscular, protrusible, 0.14 to 0.19 $\mathrm{mm}$. in diameter, with shallow saucerlike lumen or with center protruded far enough to obliterate lumen (fig. $37, b$ ) in anterior fourth of body. Ratio of diameter of oral sucker to acetabulum 1:1.2 to 1.5. Prepharynx absent. Pharynx muscular, globular, relatively small, approximately $0.03 \mathrm{~mm}$. in diameter. Esophagus very thin-walled, slender, approximately 0.19 to $0.20 \mathrm{~mm}$. long, bifurcating just in front of or dorsal to cephalic margin of acetabulum. Ceca thin-walled, dif- 
ficult to visualize in fixed specimens, of medium width, straight to slightly wavy, terminating unevenly just in front of vitellaria or somewhere within vitelline zone. Excretory pore terminal. Genital pore median, anterior to bifurcation of intestine, from one-half to threefourths the distance from oral sucker to acetabulum. Testes approximately equal in size, 0.06 to $0.18 \mathrm{~mm}$. long by 0.07 to $0.15 \mathrm{~mm}$. wide, round to oval, with smooth to slightly lobed margins, slightly oblique in position. Anterior testis immediately posterior to acetabulum or depending on state of contraction of body, may be separated from that organ by one to three uterine loops. Posterior testis entirely behind zone of anterior testis. Cirrus sac elongated-pyriform, 0.13 to 0.15 $\mathrm{mm}$. long by 0.04 to $0.05 \mathrm{~mm}$. wide, containing convoluted seminal vesicle, ejaculatory duct, and eversible cirrus, extending posteriorly far enough for one-third to two-thirds of its length to lie dorsally to acetabulum. Ovary entire, round to transversely oval, 0.04 to 0.08 $\mathrm{mm}$. long by 0.08 to $0.11 \mathrm{~mm}$. wide, on midline or slightly to one or other side of that line, separated from posterior testis by one or two loops of uterus. Seminal receptacle globular, entirely posterior to ovary, against dorsal body wall. Mehlis' gland and yolk reservoir median to seminal receptacle. Laurer's canal not observed. Vitellaria (fig. 37, c-f) consisting of 6 to 14 large irregular masses of yolk cells, individual masses joined together by distinct ducts and glands usually joined across body at their anterior limits to form a wide connecting bridge just beneath dorsal body wall. Uterus greatly convoluted, with rather indistinct loops, filling most of body posterior to vitellaria, passing anteriorly between and ventrally to vitellaria, ventrally to middle or either margin of ovary, to dorsal side of body between posterior testis and ovary, either right or left side of posterior testis between testes, dorsally to acetabulum where it forms several loops before reaching genital pore. Mature ova few in number, dark brown in color, $39 \mu$ to $44 \mu$ long by $22 \mu$ to $28 \mu$ wide.

Host.-Seiurus aurocapillus (Linnaeus).

Habitat.-Liver.

Locality.-Virginia: Mountain Lake.

Type specimen.-U.S.N.M. Helm. Coll. No. 37118.

Remarks.-Brachylecithum seiuricum is described from 18 specimens from the liver of one of 14 ovenbirds, Seiurus aurocapillus. In its combination of characters of having a slender body with suckers approximately equal in size, testes not exceeding acetabulum in size, ovary slightly smaller than testes, ceca not extending posterior to vitellaria, genital pore anterior to intestinal bifurcation and the fused vitellaria, $B$. seiuricum is unique among the already described species of the genus. From $B$. americanum and $B$. moorei, which it superficially resembles, $B$. seiuricum is readily distinguished by its more 
anterior genital pore, shorter ceca, its more posteriorly located seminal receptacle, its fused vitellaria, and its completely separated testicular zones.

\section{BRACHYLECITHUM DELICATUM, new species}

Figure $37, g-l$

Diagnosis.-Body thin, semitransparent, elongated, with almost parallel sides and rounded anterior and tapering posterior ends; it measures 1.43 to $2.18 \mathrm{~mm}$. long by 0.17 to $0.20 \mathrm{~mm}$. wide in region between posterior testis and vitellaria. Cuticle thin, aspinose, with fine transverse ridges, and with small sensory papillae on margins of body in some specimens. Oral sucker subterminal to small liplike anterior end of body, weakly muscular, elongated oval, 0.10 to $0.13 \mathrm{~mm}$. long by 0.08 to $0.10 \mathrm{~mm}$. wide. Acetabulum weakly muscular, protrusible, 0.10 to $0.14 \mathrm{~mm}$. in diameter, with center protruded (fig. 37, $h)$, in anterior fourth of body. Ratio of width of oral sucker to acetabulum 1: 1.07 to 1.41. Prepharynx absent. Pharynx muscular, globular, 0.03 to $0.04 \mathrm{~mm}$. long by $0.03 \mathrm{~mm}$. wide. Esophagus very thin walled, slender, slightly wavy, bifurcating from one-half to threefifths of distance from oral sucker to acetabulum. Ceca thin walled, of medium width, slightly wavy, with extreme terminal portions slightly dilated, terminating unevenly in zone of vitellaria or just posterior to that zone. Excretory pore terminal. Excretory vesicle thin-walled, tubular, narrow, extending anteriad to about middle of vitellaria. Genital pore median, ventral to intestinal bifurcation or slightly anterior to it. Testes round to oval, approximately equal in size, 0.08 to $0.17 \mathrm{~mm}$. long by 0.07 to $0.14 \mathrm{~mm}$. wide, with smooth to slightly lobed margins (fig. $37, i$ ) in oldest specimen, slightly oblique in position. Anterior testis located immediately posterior to acetabulum or separated from it by a single uterine loop; posterior testis entirely behind anterior one. Vasa efferentia uniting just in front of anterior testis to form a short vas deferens. Cirrus sac elongatedpyriform, 0.09 to $0.12 \mathrm{~mm}$. long by 0.03 to $0.05 \mathrm{~mm}$. wide, containing convoluted seminal vesicle, ejaculatory duct and eversible cirrus, with its posterior end at or slightly below cephalic margin of acetabulum. Ovary round to oval in shape, 0.05 to $0.12 \mathrm{~mm}$. in diameter, with smooth to slightly irregular margins, on midline or slightly to one or other side of body, separated from posterior testis by one loop of ascending uterus. Seminal receptacle globular, posterior to ovary, midway between ovary and vitellaria. Mehlis' gland and yolk reservoir posteromedial to seminal receptacle. Laurer's canal not observed. Vitellaria (fig. 37, $g, j-l$ ) consisting of 7 to 10 medium-sized irregular or transversely elongated follicles on each side of body. Vitelline ducts arise from anterior follicles on each side and pass 

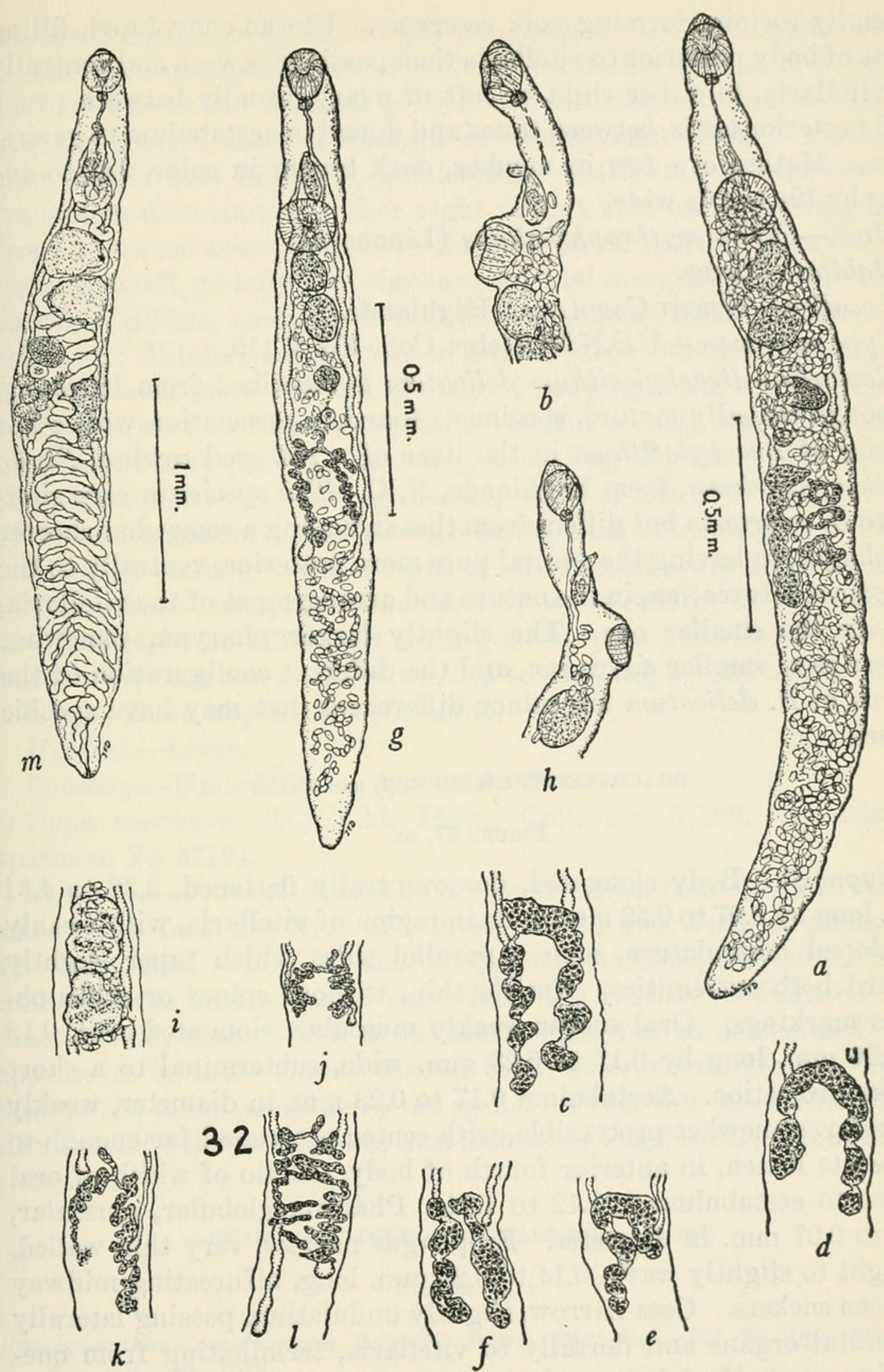

Figure 37.- a, Brachylecithum seiuricum, new species, from the liver of Seiurus aurocapillus, ventral view; $b$, lateral view of anterior end of Brachylecithum seiuricum, from Seiurus aurocapillus, showing center of acetabulum protruded; $c, d, e, f$, sketches showing the variation in the vitellaria and ends of the ceca in different specimens of Brachylecithum seiuricum, from Seiurus aurocapillus; $g$, Brachylecithum delicatum, new species, from the liver of Pipilo erythrophthalmus, ventral view; $h$, lateral view of anterior end of Brachylecithum delicatum, from Pipilo erythrophthalmus; $i$, sketch, showing the lobation of the testes in an older specimen of Brachylecithum delicatum from Pipilo erythrophthalmus; $j$, $k, l$, sketches showing the variation in the vitellaria and in the length of the ceca in Brachylecithum delicatum, from Pipilo erythrophthalmus; $m$, Brachylecithum moorei, new species, from the liver of Bubo virginianus, ventral view. 
mesially to join, forming yolk reservoir. Uterus convoluted, filling most of body posterior to vitellaria then passing between and ventrally to vitellaria, to either right or left of ovary, usually between ovary and posterior testis, between testes and dorsal to acetabulum to genital pore. Mature ova few in number, dark brown in color, $34 \mu$ to $40 \mu$ long by $19 \mu$ to $26 \mu$ wide.

\section{Host.-Pipilo erythrophthatmus (Linnaeus).}

Habitat.-Liver.

Locality.-North Carolina: Highlands.

Type specimen.-U.S.N.M. Helm. Coll. No. 37119.

Remarks.-Brachylecithum delicatum is described from 12 young, although sexually mature, specimens found in association with other species of Brachylecithum in the liver of a red-eyed towhee, Pipilo erythrophthalmus, from Highlands, N. C. The species is very similar to $B$. seiuricum but differs from that in having a somewhat shorter esophagus, in having the genital pore more posterior, ventrally to the intestinal bifurcation, in the nature and arrangement of the vitellaria, and in the smaller ova. The slightly larger pharynx, somewhat longer ceca, smaller cirrus sac, and the different configuration of the uterus in $B$. delicatum are minor differences that may have specific values.

\section{BRACHYLECITHUM MOOREI, new species}

\section{Figure $37, m$}

Diagnosis.-Body elongated, dorsoventrally flattened, 3.38 to 4.31 $\mathrm{mm}$. long by 0.27 to $0.52 \mathrm{~mm}$. wide in region of vitellaria, with weakly developed musculature, almost parallel sides which taper slightly toward both extremities. Cuticle thin, without spines or other obvious markings. Oral sucker weakly muscular, elongated-oval, 0.18 to $0.26 \mathrm{~mm}$. long by 0.17 to $0.23 \mathrm{~mm}$. wide, subterminal to a short liplike projection. Acetabulum 0.17 to $0.28 \mathrm{~mm}$. in diameter, weakly muscular, somewhat protrusible, with center protruded far enough to obliterate lumen, in anterior fourth of body. Ratio of width of oral sucker to acetabulum $1: 1.12$ to 1.21. Pharynx globular, muscular, 0.05 to $0.07 \mathrm{~mm}$. in diameter. Esophagus narrow, very thin-walled, straight to slightly wavy, 0.14 to $0.23 \mathrm{~mm}$. long, bifurcating midway between suckers. Ceca narrow, slightly undulating, passing laterally to genital organs and dorsally to vitellaria, terminating from onethird to one-half of distance from vitellaria to posterior end of body. Excretory pore terminal. Genital pore median, ventral to intestinal bifurcation. Testes large, oval, approximately equal in size, 0.20 to $0.35 \mathrm{~mm}$. in diameter, tandem in position, with zones contiguous but not overlapping in relaxed specimens. Zone of anterior testis separated from zone of acetabulum by one to three loops of uterus. Cir- 
rus sac elongated-oval, 0.20 to $0.31 \mathrm{~mm}$. long by 0.09 to $0.14 \mathrm{~mm}$. wide, containing convoluted seminal vesicle, ejaculatory duct and eversible cirrus. Cirrus sac situated so that caudal extremity reaches to or slightly beyond anterior margin of acetabulum. Ovary round to transversely oval in shape, smaller than testes, 0.13 to $0.19 \mathrm{~mm}$. in transverse diameter, on either right or left side of body, separated from posterior testis by one to three loops of uterus. Seminal receptacle small, globular, contiguous to caudal margin of ovary. Mehlis' gland diffuse, medially to seminal receptacle. Laurer's canal not observed. Vitellaria consisting of 6 to 14 large follicles on each side of body, with more follicles on side of body opposite ovary, located just posterior to seminal receptacle. Uterus greatly convoluted, filling most of body posterior to ovary, ascending to genital pore by one of three courses: (1) Passing to either right or left of ovary, between ovary and posterior testis, between testes, then anteriorly by a wavy course; (2) passing to either right or left of both ovary and posterior testis, between testes, then anteriorly by wavy course; or (3) passing to either right or left of all three gonads, then anteriorly by wavy course. Mature ova dark brown, $36 \mu$ to $44 \mu$ long by $23 \mu$ to $29 \mu$ wide.

Host.-Bubo virginianus (Gmelin).

Habitat.-Liver.

Locality.-United States (probably Texas).

Type specimen.-U.S.N.M. Helm. Coll. No. 37120. Additional specimen No. 37121.

Remarks.-Brachylecithum moorei is described from about 50 specimens taken from the liver of a great horned owl, Bubo virginianus. The host died while in the Zoological Gardens, Houston, Tex. Although the bird probably came from the vicinity of Houston, the exact locality from which it was taken could not be determined. It appears to be more closely related to $B$. americanum Denton, 1945 , than to the other members of the genus. From this species it is distinguished by the longer ceca, oval instead of lobed testes, and a larger cirrus sac.

\section{BRACHYLECITHUM AMERICANUM Denton, 1945}

Figure $38, a$

Brachylecithum americanum Denton, Journ. Parasitol., vol. 31, pp. 131-140, figs. 1-8, 1 pl., 1945.

As recently as September 1948, 18 specimens of a form identifiable as Brachylecithum americanum Denton, 1945, were removed from the liver of an immature red-shouldered hawk, Buteo lineatus (Gmelin), from Athens, Ga. This material agrees remarkably well with that from crows, Corvus brachyrhynchos Brehm, from the same locality in 
(1) size, shape, and relative position of suckers; (2) ratio of sucker sizes $(1: 1.0$ to 1.1$) ;(3)$ position of genital pore; (4) size, shape, and relative position of the genital organs; (5) number and size of vitelline follicles; and (6) the course of the uterus in ascending to genital pore. In general, specimens from the crow are slightly wider and thicker in proportion to length than specimens from birds of the family Icteridae (blackbirds). The material from the hawk is still wider and thicker in proportion to the length than are those from the crow. There seems, then, to be some evidence to indicate that there is a definite correlation between the size of the host (and its bile ducts) and the size of the specimens of this species that parasitize it.

The specimens from the hawk measure 2.28 to $2.90 \mathrm{~mm}$. long by 0.38 to $0.52 \mathrm{~mm}$. wide. The cuticle of some specimens shows fine transverse striations. The weakly muscular acetabulum shows a shallow, saucerlike lumen in some specimens, while in others the center is protruded so as to obliterate the lumen. The vasa efferentia arise from the dorsomedial surfaces of the testes and unite just in front of the anterior testis, at the caudal margin of acetabulum, to form a short vas deferens. A specimen has been deposited in the United States National Museum, Helm. Coll. No. 37123.

Since $B$. americanum has not been reported previously from any species of hawk, it is considered to be a rare parasite of this avian group. Denton and Rausch (1949) failed to find a single specimen of the species in 160 hawks, 8 of which were of the red-shouldered variety.

\section{BRACHYLECITHUM STUNKARDI (Pande, 1939), new combination}

Figure $38, b$

Lyperosomum stunkardi PANde, Proc. Nat. Acad. Sci. India, vol. 9, pp. 16-19, figs. 1-2, 1939.

Olssoniella stunkardi Travassos, Monogr. Inst. Oswaldo Cruz, No. 2, p. 221, est. 83, fig. 4 ; est. 85 , fig. $3,1944$.

Description-Body muscular, cylindrical to slightly flattened, with rounded anterior and tapering posterior ends, measuring 2.82 to $3.98 \mathrm{~mm}$. long by 0.22 to $0.30 \mathrm{~mm}$. wide in region of vitellaria. Cuticle thick, aspinose, finely wrinkled transversely. Oral sucker 0.16 to $0.23 \mathrm{~mm}$. in diameter, muscular, subterminal to a short liplike projection. Acetabulum 0.19 to $0.28 \mathrm{~mm}$. long by 0.22 to 0.35 $\mathrm{mm}$. wide, located one-sixth to one-seventh of body length from anterior end; fairly muscular, somewhat protrusible, with center often protruded so as to obliterate its lumen; with a small, flat appendage on each lateral margin. Ratio of width of oral sucker to acetabulum $1: 1.35$ to $1: 1.75$. Pharynx muscular, 0.05 to $0.07 \mathrm{~mm}$. in diameter. Esophagus in relaxed specimens narrow, 0.20 to $0.32 \mathrm{~mm}$. long, 
straight to slightly wavy, bifurcating dorsal to cephalic margin of acetabulum. Ceca slender, becoming bulbous toward posterior ends in some specimens, slightly sinuous, terminating at different levels,
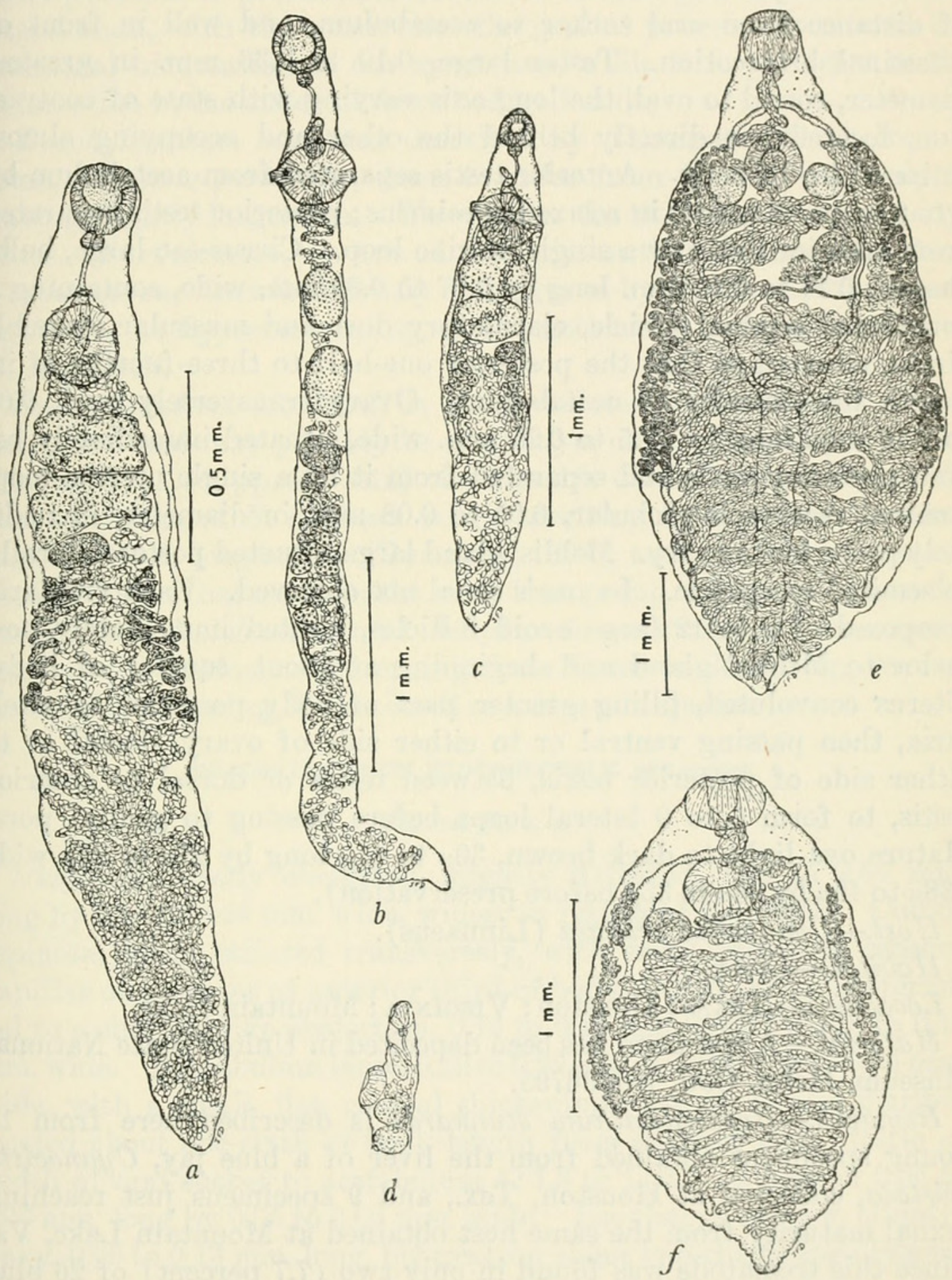

FigURe 38.- a, Brachylecithum americanum Denton, 1945, from the liver of Buteo lineatus, ventral view (the testes are tandem in position rather than oblique as they usually are); b, Brachylecithum stunkardi (Pande, 1939), from the liver of Cyanocitta cristata, ventral view; c, Brachylecithum exochocotyle, new species, from the liver of Toxostoma rufum, ventral view; d, lateral view of anterior end of Brachylecithum exochocotyle, from Toxostoma rufum, showing position of suckers and shallow lumen of acetabulum; $e$, Lubens lubens (Braun, 1901), from the gall bladder of Cassidix mexicanus prosopidicola, ventral view; $f$, Lubens lubens, from the gall bladder of Piranga olivacea, ventral view. 
from one-fourth to one-half the distance from vitellaria to posterior end of body. Excretory pore terminal. Excretory vesicle tubular, voluminous, and somewhat sinuous, extending anteriorly to level of posterior vitelline follicles. Genital pore median, about two-thirds of distance from oral sucker to acetabulum, and well in front of intestinal bifurcation. Testes large, 0.10 to $0.36 \mathrm{~mm}$. in greatest diameter, round to oval, the long axis varying with state of contraction, located one directly behind the other and occupying almost entire width of body. Anterior testis separated from acetabulum by 6 to 9 loops of uterus in relaxed specimens; posterior testis separated from anterior testis by a single uterine loop. Cirrus sac large, bulbshaped, 0.14 to $0.19 \mathrm{~mm}$. long by 0.07 to $0.09 \mathrm{~mm}$. wide, containing a convoluted seminal vesicle, ejaculatory duct and muscular eversible cirrus, situated so that the posterior one-half to three-fourths of its length lies dorsally to acetabulum. Ovary transversely oval, 0.07 to $0.19 \mathrm{~mm}$. long by 0.15 to $0.25 \mathrm{~mm}$. wide, situated immediately behind posterior testis and separated from it by a single uterine loop. Seminal receptacle globular, 0.05 to $0.08 \mathrm{~mm}$. in diameter, immediately posterior to ovary. Mehlis' gland large, situated posterolaterally to seminal receptacle. Laurer's canal not observed. Each vitellaria composed of 8 to 12 large ovoid follicles, located immediately posterior to Mehlis' gland and beginning at about equator of body. Uterus convoluted, filling greater part of body posterior to vitellaria, then passing ventral or to either side of ovary, dorsal or to either side of posterior testis, between testes or dorsal to anterior testis, to form 6 to 9 lateral loops before passing to genital pore. Mature ova light to dark brown, $30 \mu$ to $41 \mu$ long by $21 \mu$ to $27 \mu$ wide ( $38 \mu$ to $45 \mu$ by $28 \mu$ to $33 \mu$ before preservation).

Host.-Cyanocitta cristata (Linnaeus).

Habitat.-Liver.

Localities.-Texas: Houston; Virginia : Mountain Lake.

Material.-A specimen has been deposited in United State National Museum, Helm. Coll. No. 36795.

Remarks.-Brachylecithum stunkardi is described here from 16 young specimens obtained from the liver of a blue jay, Cyanocitta cristata, collected at Houston, Tex., and 9 specimens just reaching sexual maturity from the same host obtained at Mountain Lake, Va. Since this trematode was found in only two ( 7.7 percent) of 26 blue jays examined from various localities, it apparently is not very common in this host.

The material in the present collection, although slightly smaller and possibly younger, agrees very closely with that described by Pande (1939) in (1) shape of the body; (2) size, shape, and relative position of the suckers; (3) size, shape, and relative position of geni- 
tal organs; (4) position of the genital pore; (5) position and shape of vitellaria; (6) course of the uterus; and (7) size of ova. Our material differs from Pande's in having the intestinal bifurcation more posterior in position; it lies dorsal to the cephalic portion of the acetabulum, with the result that the genital pore is anterior to the intestinal bifurcation in our specimens, while it is posterior to the bifurcation in the material described by Pande.

Brachylecithum eophonae described by Yamaguti (1941) from a finch, Eophona personata, seems to differ from $B$. stunkardi only in having slightly larger ova. We consider the two forms to be synonymous. Furthermore, we are of the opinion that the material from Corvus corone described briefly and figured by Braun (1902, plate 6, figure 66) as Lyperosomum $\mathrm{sp}$. is unquestionably a representative of B. stunkardi.

Brachylecithum stunkardi is closely related to B. lobatum (Railliet, 1900) and may possibly be a synonym of it. As pointed out by Travassos (1944, pp. 210-212) considerable confusion concerning the characteristics of $B$. lobatum exists, resulting from authors' confusing it with L. longicauda (Rudolphi, 1809), and possibly with other similar forms that occur in the same host group. Until adequate descriptions of $B$. lobatum and $L$. longicauda are available for comparison and the confusion concerning these forms is cleared up, we feel justified in retaining $B$. stunkardi as a separate species.

\section{BRACHYLECITHUM EXOCHOCOTYLE, new species}

\section{Figure 38, $c, d$}

Diagnosis.-Body elongated, slightly flattened, 1.42 to $2.50 \mathrm{~mm}$. long by 0.28 to $0.59 \mathrm{~mm}$. wide, widest in region of vitellaria. Cuticle aspinose, finely striated transversely, with small retractile sensory papillae on margins of anterior third of body. Oral sucker subterminal to a short liplike projection, 0.16 to $0.18 \mathrm{~mm}$. long by 0.15 to 0.17 $\mathrm{mm}$. wide. Acetabulum large, 0.22 to $0.28 \mathrm{~mm}$. long by 0.28 to $0.35 \mathrm{~mm}$. wide, with a small, flat, conical thickening on each lateral margin, located about one-sixth of body length from anterior end. Ratio of width of oral sucker to acetabulum $1: 1.8$ to $1: 2.1$. Pharynx 0.05 to $0.07 \mathrm{~mm}$. long by 0.06 to $0.09 \mathrm{~mm}$. wide. Esophagus narrow, slightly wavy, 0.09 to $0.13 \mathrm{~mm}$. long, bifurcating about two-thirds the distance from oral sucker to acetabulum. Ceca slender, slightly sinuous, terminating a short distance posterior to vitellaria. Excretory pore terminal. Genital pore median, ventral to intestinal bifurcation. Testes conspicuously large, transversely oval, 0.14 to $0.25 \mathrm{~mm}$. long by 0.22 to $0.46 \mathrm{~mm}$. wide, located one immediately behind the other, with anterior one contiguous to or slightly overlapping zone of acetabulum. Cirrus sac large, oval, 0.13 to $0.19 \mathrm{~mm}$. long by 0.08 to $0.13 \mathrm{~mm}$. wide, contain- 
ing coiled seminal vesicle and eversible cirrus, with approximately posterior half lying dorsally to anterior margin of acetabulum. Ovary oval in shape, small, 0.07 to $0.12 \mathrm{~mm}$. long by 0.11 to $0.17 \mathrm{~mm}$. wide, located immediately behind posterior testis, lateral in position, with outer margin pressed close against either right or left cecum. Seminal receptacle large, globular, located posteromedially to ovary. Vitellaria composed of 8 to 12 large oval follicles on each side of body, located immediately posterior to ovary. Uterus convoluted filling greater part of body posterior to ovary, then passing to either right or left of posterior testis and ovary, dorsal to anterior testis, to describe two or three lateral loops dorsal to acetabulum before ascending to genital pore. Mature ova dark brown, $46 \mu$ to $53 \mu$ long by $27 \mu$ to $32 \mu$ wide.

Host.-Toxostoma mufum (Linnaeus).

Habitat.-Liver.

Locality.-Georgia : Athens.

Type specimen.-U.S.N.M. Helm. Coll. No. 37122. Additional specimens, Nos. 36755 and 36756 .

Remarks.-Brachylecithum exochocotyle is described from more than 75 specimens removed from the liver of a brown thrasher, Toxostoma rufum, obtained at Athens, Ga. This infection, the only one (2.44 percent) encountered in 41 brown thrashers examined from various localities, occurred as a double infection with Lyperosomum oswaldoi. The bird, which was found in a dying condition with its liver almost completely destroyed, was the only host examined that showed definite evidence of being harmed by its dicrocoeliid infections.

Brachylecithum exochocotyle can be separated from $B$. stunkardi, which it resembles very closeiy, by its shorter and wider body, its relatively smaller oral sucker, its large oval testes, its relatively smaller ovary, and especially in the difference in size and appearance of the vitelline follicles.

Genus ATHESMIA Looss, 1899

ATHESMIA HETEROLECithodeS (Braun, 1899)

Figure $36, f$

Distomum heterolecithodes Braun, Zool. Anz., vol. 22, p. 3, 1899.

Athesmia reelfooti Denton, in Petri, Trans. Amer. Micr. Soc., vol. 61, p. 60, 1942.

A single mature specimen belonging to the genus Athesmia was dissected from the liver of a Florida gallinule, Gallinula chloropus cachinnans Bangs, collected at Reelfoot Lake, Tenn. It is possible to assign this material to $A$. heterolecithodes (Braun, 1899), although our specimen differs somewhat from this species as redescribed by Jacoby $(1899 \mathrm{a}, \mathrm{b})$ in having a narrower and longer body, relatively shorter ceca, more posterior genital pore, and a smaller cirrus pouch. 
The differences noted, except possibly the difference in the size of the cirrus pouch, can be attributed to a difference in the state of body contractions. Since this is the first time A. heterolecithodes has been reported from the New World, a detailed description of the specimen is given below.

Description.-Body slender and semitransparent, approximately $11.4 \mathrm{~mm}$. long by $0.69 \mathrm{~mm}$. wide at level of acetabulum; sides almost parallel. Cuticle thin, without spines. Oral suckers subterminal, $0.44 \mathrm{~mm}$. long by $0.43 \mathrm{~mm}$. wide. Acetabulum smaller, $0.36 \mathrm{~mm}$. in diameter, situated about one-seventh of body length from anterior end. Pharynx $0.10 \mathrm{~mm}$. in diameter. Esophagus narrow and straight, $0.39 \mathrm{~mm}$. long, bifurcating about two-fifths the distance from oral sucker to acetabulum. Ceca slender, unequal in length, extending to about level of caudal extremity of vitellarium. Excretory pore terminal. Genital pore median, a short distance posterior to intestinal bifurcation. Anterior testis $0.51 \mathrm{~mm}$. long by $0.26 \mathrm{~mm}$. wide, irregular in outline, deeply fissured on lateral margins, situated toward same side of body as vitellarium. Posterior testis $0.52 \mathrm{~mm}$. long by $0.26 \mathrm{~mm}$. wide, of same shape as anterior testis, situated on opposite side of body, $0.87 \mathrm{~mm}$. behind level of anterior testis. Cirrus sac pear-shaped, $0.24 \mathrm{~mm}$. long by $0.14 \mathrm{~mm}$. wide, containing coiled seminal vesicle and eversible cirrus. Ovary small, $0.16 \mathrm{~mm}$. long by $0.27 \mathrm{~mm}$. wide, deeply lobed, situated preequatorily on opposite side of body from vitellarium. Seminal receptacle large, globular, just posterior to ovary. Mehlis' gland at posteromedial margin of seminal receptacle. Vitellarium unilateral, consisting of numerous small follicles, divided into one large and two small groups, extending from level of Mehlis' gland through a distance of $3.43 \mathrm{~mm}$. on right side of body. Uterus with many coils, descending first to posterior end of body, then ascending, passing to right of ovary and posterior testis, to left of anterior testis and dorsal to acetabulum and cirrus sac to genital pore. Mature ova dark brown, $33 \mu$ to $38 \mu$ long by $23 \mu$ to $25 \mu$ wide.

Additional host.-Gallinula chloropus cachinnans Bangs.

Habitat.-Liver.

Locality.-Tennessee : Reelfoot Lake.

Material.-The specimen has been deposited in the United States National Museum, Helm. Coll. No. 36732.

\section{Genus LUBENS Travassos, 1920}

LUBENS LUBENS (Braun, 1901)

Figure $38, e, f$

Dicrocoelium lubens Braun, Centralbl. Bakt. Parasit., vol. 29, p. 945, 1901. Euritrema (Lubens) lubens Travassos, Arch. Esc. Sup. Agr. e Med. Vet. Nictheroy, vol. 3 (1919), pp. 19-20, 1920. 
Lubens lubens (Braun, 1901) Sтrom, Parasitol. Sborn. Zool. Inst. Acad. Nauk U. S. S. R., vol. 8, p. 180, 1940.

Description.-Body thick and broadly oval, tapering toward extremities, measuring 5.36 to $5.64 \mathrm{~mm}$. long by 2.25 to $2.64 \mathrm{~mm}$. wide, widest near posterior end of vitellaria. Cuticle thick, without spines, transversely wrinkled, and with retractile sensory papillae on the preacetabular margins of body. Oral sucker muscular, subterminal in position, oval in shape and measuring 0.42 to $0.47 \mathrm{~mm}$. in diameter. Acetabulum muscular, 0.42 to $0.50 \mathrm{~mm}$. in diameter, situated relatively close to oral sucker within anterior fourth of body. Ratio of sucker diameters about $1: 1$. Pharynx large, globular, $0.16 \mathrm{~mm}$. long by 0.19 to $0.21 \mathrm{~mm}$. wide. Esophagus short, straight, approximately equal in length to pharynx. Intestine bifurcating at approximately twothirds the distance from oral sucker to acetabulum. Ceca narrow, slightly sinuous, passing dorsal to lateral margins of testes and medial margins of vitellaria to terminate about midway between ends of vitellaria and posterior end of body. Excretory pore terminal. Excretory vesicle tubular and voluminous, extending anteriad to about equator of body where it receives a common collecting tubule from each side of body. Each common collecting tubule passing anterolateral to posterior level of testes where it divides into an anterior and posterior main collecting tubule. Genital pore median, at posterior level of pharynx. Testes rounded, approximately equal in size, 0.30 to $0.50 \mathrm{~mm}$. in diameter, situated directly opposite each other, lateral to the acetabulum with their zones lying almost entirely within that of acetabulum. Cirrus sac small, club-shaped, $0.38 \mathrm{~mm}$. long by 0.11 $\mathrm{mm}$. wide (single specimen), extending slightly posterior to intestinal bifurcation, containing convoluted seminal vesicle, prostatic gland cells, and eversible cirrus. Ovary rounded, 0.28 to $0.43 \mathrm{~mm}$. in diameter situated either to right or left side of body close behind the respective testis. Seminal receptacle small, situated dorsal to posteromedial margin of ovary. Mehlis' gland diffuse, located ventral to medial margin of seminal receptacle. Vitellaria composed of numerous oval follicles, situated in lateral margins of body, extending posteriorly from within zone of acetabulum for a distance of 2.67 to $2.96 \mathrm{~mm}$. (or about half the total body length). Vitelline ducts arising at point approximately midway the vitellaria. Uterus very voluminous and greatly convoluted, filling most of postacetabular region of body and sending characteristic loops lateral to testes to anterior level of acetabulum before following a wavy course to genital pore. Mature ova numerous, dark brown, $26 \mu$ to $31 \mu$ long by $17 \mu$ to $23 \mu$ wide, fully embryonated when oviposited. Miracidium symmetrical, ciliated, possessing a stylet and having two large oval oppositely situated 
vesicles in the posterior half of body; vesicles containing highly refractile granules.

Additional hosts.-Cassidix mexicanus prosopidicola Lowery and Piranga olivacea (Gmelin).

Habitat.-Gall bladder.

Localities.-Texas, Eagle Lake; Virainia, Mountain Lake.

Material.-A specimen from the mesquite grackle has been deposited in the United States National Museum, Helm. Coll. No. 36746.

Remarks.-The above description of Lubens tubens is based on four mature specimens from the gall bladders of two of nine mesquite grackles, Cassidixmexicanus prosopidicola, collected at Eagle Lake, Tex. The infected birds contained one and three worms, respectively, and each was infected with another species of dicrocoeliid trematode. These specimens fit perfectly into the present concept of $L$. lubens, which was recently expanded by Travassos (1944) to include four former species and specimens from 27 different hosts. This species has not heretofore been reported from North America or any place outside of Brazil.

In addition to the worms from the mesquite grackles, a single mature specimen of this species was found in the gall bladder of a scarlet tanager, Piranga olivacea, collected at Mountain Lake, Va. This specimen (fig. $38, f$ ), although it is sexually mature and has the uterus distended with eggs, measures only $2.45 \mathrm{~mm}$. long by $1.51 \mathrm{~mm}$. wide. The oral sucker measures $0.27 \mathrm{~mm}$. long by $0.39 \mathrm{~mm}$. wide. The acetabulum $0.29 \mathrm{~mm}$. long by $0.39 \mathrm{~mm}$. wide. Ratio of oral sucker to acetabulum $1: 1$. The testes measure $0.21 \mathrm{~mm}$. and $0.24 \mathrm{~mm}$. in greatest diameter. The ovary is $0.18 \mathrm{~mm}$. long by $0.27 \mathrm{~mm}$. wide. The vitellaria extend $0.95 \mathrm{~mm}$. along the sides of the body. The cirrus pouch measures $0.16 \mathrm{~mm}$. long by $0.08 \mathrm{~mm}$. wide. The ova are $40 \mu$ to $43 \mu$ long by $23 \mu$ to $24 \mu$ wide.

\section{Genus CONSPICUUM Bhalerao, 1936}

\section{CONSPICUUM ICTERIDORUM, new species}

Figure 39, $a, b$

Diagnosis.-Body fairly thick and muscular, elongated oval, tapering to posterior end, 2.20 to $5.97 \mathrm{~mm}$. long by 0.70 to $1.97 \mathrm{~mm}$. wide, widest in region between testes and ovary. Cuticle thick, without spines, smooth or with fine transverse wrinkles when slightly contracted. An undetermined number of small retractile sensory papillae visible on lateral margins of anterior half of body; papillae much more numerous on the inconspicuous dorsal liplike projection and along lateral margins of oral sucker. Oral sucker strongly muscular, subterminal, 0.20 to $0.58 \mathrm{~mm}$. in diameter. Acetabulum large and muscular, with deep cup-shaped lumen, situated at junction of ante- 
rior and middle body thirds; it measures 0.38 to $0.82 \mathrm{~mm}$. in diameter. Ratio of diameter of oral sucker to acetabulum varying from 1:1.3 to 1 :1.9. Prepharynx absent. Pharynx globular, 0.08 to $0.23 \mathrm{~mm}$. in diameter. Esophagus narrow, usually slightly wavy, 0.08 to 0.40 $\mathrm{mm}$. long, bifurcating one-half to two-thirds the distance from oral sucker to acetabulum. Ceca of medium width, straight to slightly wavy, passing outside of lateral margins of testes to terminate about midway between ends of vitellaria and posterior end of body. Cerebral ganglion conspicuous, ventral to posterior margin of pharynx. Excretory pore terminal. Excretory vesicle (fig. 39, $b$ ) simple, tubular, extending anteriorly through about one-third of body length, receiving a common collecting tubule from each side. Each common collecting tubule rather voluminous, passing anterolaterally between testes and acetabulum to divide into an anterior and posterior main collecting tubule at level of equator of acetabulum. Each anterior and posterior main collecting tubule on each side of body giving rise to three short accessory tubules. Each accessory tubule branching into a dorsal and ventral capillary tubule, each of which terminates in a single flame cell. Flame cell pattern $2[(2+2+2)+(2+2+2)]$. Genital pore median, at level of pharynx. Testes rounded, 0.09 to $0.45 \mathrm{~mm}$. in diameter, situated directly opposite with their fields widely separated and their zones immediately behind or overlapping that of acetabulum. Vasa efferentia arising from anteromedial margin of testes and passing anteriorly and medially to unite as they enter cirrus sac. Cirrus sac elongated, 0.24 to $0.73 \mathrm{~mm}$. long by 0.09 to $0.34 \mathrm{~mm}$. wide, containing a convoluted seminal vesicle, ejaculatory duct surrounded by prostatic gland cells and eversible cirrus; it usually lies entirely in front of acetabulum. Ovary round to transversely oval, 0.10 to $0.36 \mathrm{~mm}$. in greatest diameter, situated submedially, relatively far from testes. Seminal receptacle globular, located dorsal or posterior to caudal margin of ovary. Mehlis' gland situated medially to seminal receptacle. Laurer's canal present. Vitellaria composed of numerous medium-sized oval follicles, mainly extracecal, extending posteriorly from within testicular zones for a distance of 0.82 to 2.11 $\mathrm{mm}$. (about two-thirds distance to posterior end of body). Vitelline ducts arising from about middle of vitellaria. Uterus convoluted, filling most of posttesticular region of body, then following an undulating course to genital pore. Mature ova dark brown, $27 \mu$ to $33 \mu$ long by $17 \mu$ to $23 \mu$ wide, fully embryonated with oviposited. Miracidium symmetrical, ciliated, possessing a stylet and with two large oppositely situated vesicles in the posterior half of body; vesicles containing highly refractile granules.

Hosts.-Quiscalus quiscula aeneus Ridgway (type), Quiscalus quiscula quiscula (Linnaeus), Cassidix mexicanus prosopidicola 
Lowery, Cassidix mexicanus major (Vieillot), Euphagus Carolinus (Müller), and Sturnella magna argutula Bangs.

Habitat.-Gall bladder.
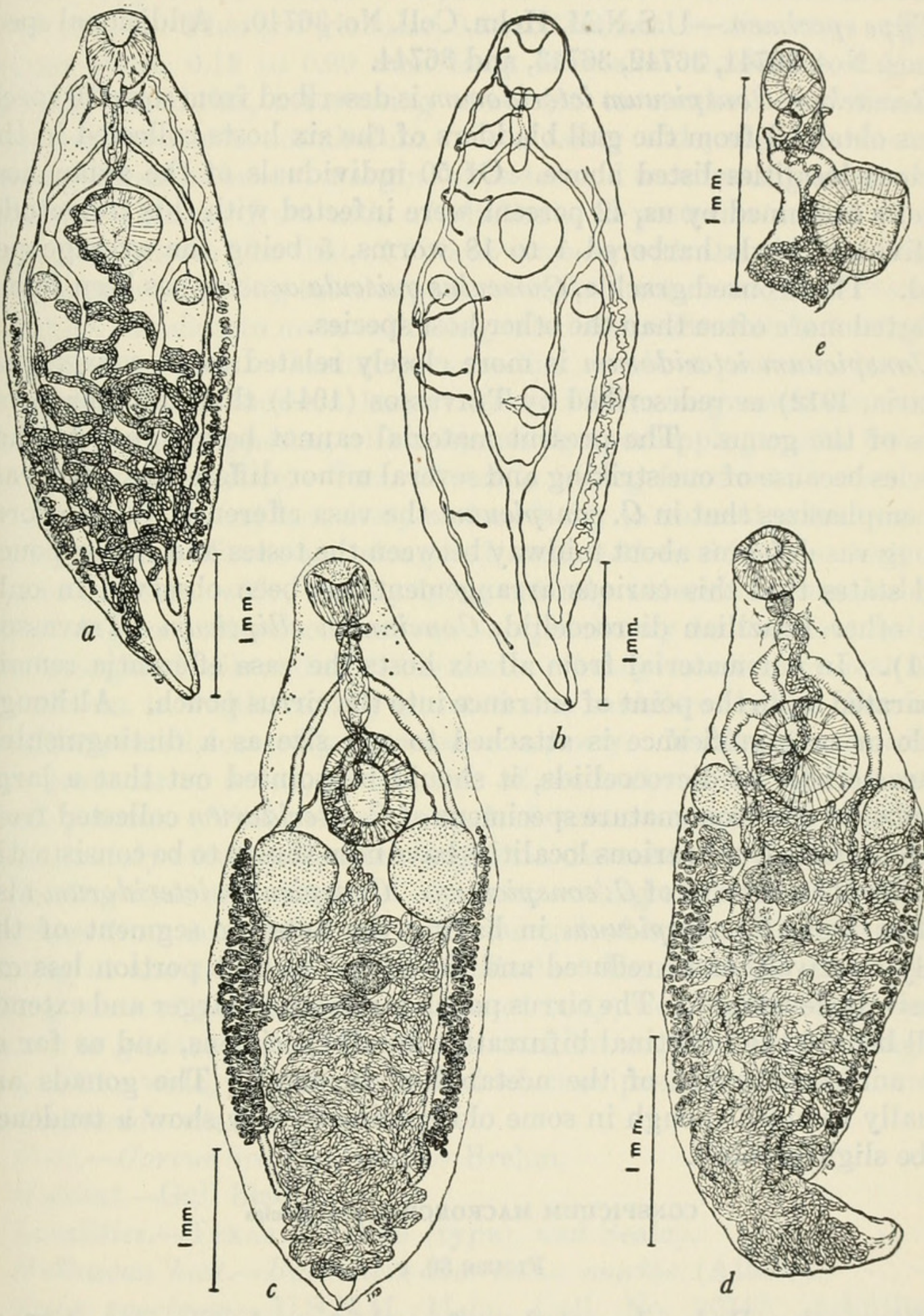

Figure 39.- a, Conspicuum icteridorum, new species, from the gall bladder of Quiscalus quiscula aeneus, ventral view; $b$, excretory system of Conspicuum icteridorum (freehand sketch on camera lucida outline); $c$, Conspicuum macrorchis, new species, from gall bladder of Corous brachyrhynchos, ventral view; $d$, Zonorchis alveyi (Martin and Gee, 1949), from the gall bladder of Pipilo erythrophthalmus, ventral view; $e$, optical sagittal section of anterior end of Zonorchis alveyi, from Pipilo erythrophthalmus, showing relative position of organs and deep lumen of acetabulum. 
Localities.-Texas: Eagle Lake (type), and Houston; Tennessee : Nashville, Stone River Park, Mount Juliet, and Reelfoot Lake; Georgia : Augusta and Athens; Michigan : East Lansing.

Molluscan host.-Deroceras laeve (Müller).

Type specimen.-U.S.N.M. Helm. Coll. No. 36740. Additional specimens, Nos. $36741,36742,36743$, and 36744.

Remarks.-Conspicuum icteridorum is described from some 70 specimens obtained from the gall bladders of the six hosts collected in the various localities listed above. Of 50 individuals of the avian host species examined by us, 42 percent were infected with this trematode. Individual birds harbored 1 to 18 worms, 5 being the average per bird. The bronzed grackle, Quisculus quiscula aeneus, has been found infected more often than the other host species.

Conspicuum icteridorum is more closely related to $C$. conspicuum (Faria, 1912) as redescribed by Travassos (1944) than to other members of the genus. The present material cannot be assigned to that species because of one striking and several minor differences. Travassos emphasizes that in $C$. conspicuum the vasa efferentia fuse to form a long vas deferens about midway between the testes and cirrus pouch and states that this curious arrangement has been observed in only one other Brazilian dicrocoeliid, Concinnum ellipticum (Travassos, 1941). In our material from all six hosts the vasa efferentia remain separated up to the point of entrance into the cirrus pouch. Although little or no significance is attached to egg size as a distinguishing characteristic of dicrocoeliids, it should be pointed out that a large number of ova from mature specimens of $C$.icteridorum collected from various hosts from various localities have been shown to be consistently smaller than the ova of $C$. conspicuum. Conspicuum icteridorum also differs from $C$. conspicurm in having the anterior segment of the body relatively more reduced and the uterus in that portion less extensively developed. The cirrus pouch is relatively larger and extends well behind the intestinal bifurcation in all specimens, and as far as the anterior margin of the acetabulum in many. The gonads are usually rounded though in some old specimens they show a tendency to be slightly lobed.

\section{CONSPICUUM MACRORCHIS, new species}

Figure 39, $c$

Diagnosis.-Body elongated, rather thick and muscular, 4.27 to $5.47 \mathrm{~mm}$. long by 1.40 to $2.04 \mathrm{~mm}$. wide, widest in region between testes and ovary. Cuticle thick, without spines, longitudinally striated and finely wrinkled transversely, and with retractile sensory papillae, which are visible only on margins of preacetabular region of body. Oral sucker strongly muscular, subterminal, preceded dorsally by a 
fairly prominent liplike projection; it measures 0.30 to $0.50 \mathrm{~mm}$. in diameter. Acetabulum large, 0.55 to $0.84 \mathrm{~mm}$. in diameter, muscular, with deep cup-shaped lumen, situated at junction of anterior and middle body thirds. Ratio of diameter of oral sucker to acetabulum $1: 1.5$ to $1: 2$. Pharynx globular, 0.14 to $0.24 \mathrm{~mm}$. in diameter. Esophagus short, 0.15 to $0.20 \mathrm{~mm}$. long, somewhat thickened and apparently glandular, bifurcating one-third to one-half the distance from oral sucker to acetabulum. Ceca fairly wide, slightly sinuous, passing dorsal to lateral margins of testes and terminating about onethird the distance from ends of vitellaria to posterior end of body. Excretory system like that of $C$. icteridorum, with the exception that the common collecting tubules pass ventral to inner margins of testes, and these divide into main collecting tubules at ventromedial margins of the male organs. Genital pore median, at about posterior level of pharynx. Testes rounded, large, 0.25 to $0.77 \mathrm{~mm}$. in greatest diameter, situated directly opposite, with zones partly overlapping caudal boundary of acetabular zone. Vasa efferentia arising from anterior margin of testes and passing anteriorly and medially to unite at entrance into cirrus pouch. Cirrus sac elongated oval, 0.33 to $0.66 \mathrm{~mm}$. long by 0.12 to $0.19 \mathrm{~mm}$. wide, usually lying entirely anterior to acetabulum, containing convoluted seminal vesicle, ejaculatory duct surrounded by prostatic gland cells and eversible cirrus. Ovary transversely oval, 0.30 to $0.37 \mathrm{~mm}$. in width, usually situated near middle of body. Seminal receptacle small, located just posterior to ovary. Mehlis' gland medial, just posterior to ovary, at one side of seminal receptacle. Laurer's canal present. Vitellaria composed of numerous medium-sized follicles, mainly extracecal, extending for a distance of 1.73 to $2.28 \mathrm{~mm}$., beginning near anterior level of testes, ending about two-thirds the distance from acetabulum to posterior end of body. Vitelline ducts arising at about middle of the vitellaria. Uterus much convoluted, filling most of posttesticular region of body, then following a wavy course to genital pore. Mature ova dark brown, $27 \mu$ to $31 \mu$ long by $19 \mu$ to $21 \mu$ wide, fully embryonated when oviposited. Miracidium as in $C$. icteridorum.

Host.-Corvus brachyrhynchos Brehm.

Habitat.-Gall bladder.

Localities.-Texas: Clodine (type), and Sealey.

Molluscan host.-Bulimulus alternatus mariae (Albers).

Type specimen.-U.S.N.M. Helm. Coll. No. 36747. Additional specimen, No. 36748 .

Remarks.-Conspicuum macrorchis is described from 47 mature specimens from the gall bladder of 4 of 10 crows, Corvus brachyrhynchos, examined from Clodine and Sealey, Tex. Individual hosts harbored $6,8,8$, and 25 worms, respectively. Crows examined from 
other localities have failed to yield specimens of this species suggesting that its range coincides with that of the molluscan intermediate host.

Conspicuum macrorchis is closely related to $C$. icteridorum, but may be easily distinguished from it by its larger and decidedly more muscular body, its more extensively developed vitellaria and uterus and its conspicuously larger testes.

Genus ZONORCHIS Travassos, 1944

ZONORCHIS ALVEYI (Martin and Gee, 1949), new combination

Figure $39, d, e$

Eurytrema alveyi Martin and Gee, Journ. Parasitol., vol. 35, pp. 61-66, 2 figs., 1949.

The material in the present collection, consisting of 48 mature specimens, agrees very closely with that recently described as Eurytrema alveyi by Martin and Gee (1949) in size and arrangement of internal organs. Our largest specimens are slightly longer than the original material; they measure $5.42 \mathrm{~mm}$. in length. The "small protuberances" reported on the cuticula of the anterior body region of the type material are conical, retractile, sensory papillae, and are not to be confused with the tuberculations on the cuticle of Brachylecithum rarum and $B$. tuberculatum. The acetabulum (fig. 39, e), which is strongly muscular, with a deep cup-shaped lumen, is situated at the junction of the anterior and middle body-thirds. The ratio of the diameter of the oral sucker to acetabulum varies from $1: 1.3$ to $1: 1.5$. Not stressed in the original description is the characteristic manner in which the ceca pass dorsal to the medial margins of the testes, forcing these organs against the lateral body walls. The ceca continue posteriorly some distance beyond the testes, medially to the vitellaria. The ovary, which is shallowly but distinctly lobed in all of our specimens, lies slightly to the left of the midline as often as to the right of that line. The uterus, which fills most of the postacetabular region of the body, forms characteristic anteriorly directed loops between the acetabulum and testes before ascending to the genital pore by a slightly wavy course.

Although the complete excretory system could not be worked out from our specimens, sufficient details could be seen to indicate that the system differs from that described for the type material. In our material the common collecting tubules pass anteriorly and laterally, dorsal to the medial margins of the testes, to bifurcate into anterior and posterior main collecting tubules at the level of the equator of the acetabulum (or dorsal to anterior margins of testes). Each of the anterior main collecting tubules gives rise to three accessory tubules which branch almost immediately into dorsal and ventral 
capillary tubules. Of the anterior pair of capillary tubules, one extends straight anteriorly along the oral sucker and the other turns ventrally at right angles along the posterior wall of the sucker. The middle pair of capillaries arises at approximately the posterior level of the cirrus sac; one passes ventrally in an anteromedial direction, the other dorsally and medially toward the posterior end of the cirrus sac. The posterior pair of capillaries arises just a short distance anterior to the junction of the anterior and posterior main tubules; one passes anteromedially toward the anterior margin of the acetabulum while the other one passes medially toward the center of the acetabulum. The origin and number of capillaries arising from the posterior main collecting tubules could not be determined. However, it seems logical that three pairs of capillaries also arise from each of the posterior main collecting tubules, as described for other species of Dicrocoeliinae, and that the complete system is very similar to that described for Conspicuum icteridorum.

Zonorchis alveyi was described originally from specimens from the gall bladder of the slate-colored junco, Junco hyemalis (Linnaeus), from the vicinities of Lafayette and Greencastle, Ind. The present paper reports specimens from the gall bladder of the red-eyed towhee, Pipilo erythrophthalmus (Linnaeus), from Mountain Lake, Va., Highlands, N. C., and Athens, Ga.; from the white-throated sparrow, Zonotrichia albicollis (Gmelin), from Houston, Tex.; from a white-

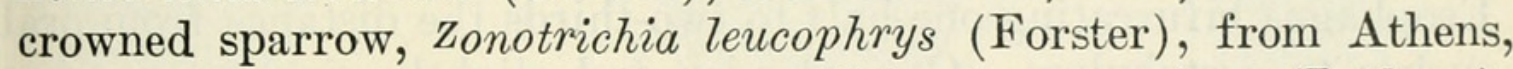
Ga.; and from the swamp sparrow, Melospiza georgiana (Latham), and a song sparrow, Melospiza melodia (Wilson), from Augusta, Ga. Individual birds harbored one to eight worms, four being the average per bird. The red-eyed towhee has been found infected more often than the other hosts and harbored the largest number of worms. Two specimens, No. 36738 from the red-eyed towhee and No. 36739 from the white-throated sparrow, have been deposited in the helminthological collection of the United States National Museum.

We do not agree with Martin and Gee (1949) in assigning this form to the genus Eurytrema. The shape of the body, the location of the genital pore (ventral to the pharynx), the nature and extent of the vitellaria, together with the fact that the acetabulum is larger than the oral sucker (about $1.4: 1$ ), definitely indicate affinities with members of the genus Zonorchis Travassos, 1944. The proper designation of the species, then, is Zonorchis alveyi (Martin and Gee, 1949), new combination. In describing $Z$. alveyi (=Eurytrema alveyi) the authors compared it only with Concinnum ludovicianae (Petri, 1942) Travassos, 1944, a form to which it has only a superficial resemblance. From other species of the genus Zonorchis, with which it appears to be more closely related than to species of the genus Concinnum, $Z$. alveyi 
can be readily distinguished by the manner in which its fairly wide ceca pass medially to the testes and vitellaria, and in having the common collecting tubules of the excretory system pass dorsal to the medial margins of the testes.

\section{ZONORCHIS PETIOLATUM (Railliet, 1900), new combination}

Figure $40, a-d$

Dicrocoelium petiolatum Railliet, Comp. Rend. Soc. Biol., vol. 52, p. 241, 1900. Eurytrema sp. Denton, in Petri, Trans. Amer. Micr. Soc., vol. 61, p. 61, 1942. Lyperosomum petiolatum Travassos, Monogr. Inst. Oswaldo Cruz, No. 2, pp. 136137, est. 45, figs. $3-6,1944$.

Description: Body spindle-shaped when relaxed, fairly thick and muscular, 2.26 to $4.18 \mathrm{~mm}$. long by 0.34 to $0.92 \mathrm{~mm}$. wide, widest in region between testes and ovary. Cuticle without spines and with small retractile sensory papillae, which are more visible on margins of anterior half of body. Oral sucker muscular, 0.13 to $0.20 \mathrm{~mm}$. in diameter, subterminal in position and preceded dorsally by a fairly prominent liplike projection. Acetabulum muscular, with deep cupshaped lumen, much larger than oral sucker, 0.25 to $0.40 \mathrm{~mm}$. in diameter, situated within anterior fourth of body. Ratio of diameter of oral sucker to acetabulum varying from $1: 1.7$ to $1: 2.19$. Pharynx globular, 0.05 to $0.10 \mathrm{~mm}$. in diameter. Esophagus narrow, usually straight, 0.10 to $0.13 \mathrm{~mm}$. long, surrounded by minute gland cells. Esophagus bifurcating one-half to two-thirds the distance from oral sucker to acetabulum. Ceca slender and slightly sinuous, passing dorsolaterally to margins of testes, terminating approximately onehalf the distance from vitellaria to posterior end of body. Excretory pore terminal. Excretory vesicle tubular and voluminous, extending anteriad almost to Mehlis' gland, receiving a common collecting tubule from each side of body. Each common collecting tubule passing anterolaterad to level of equator of testes where it branches into an anterior and posterior main collecting tubule. Genital pore median at about posterior level of pharynx. Testes rounded, 0.09 to $0.20 \mathrm{~mm}$. in greatest diameter, situated directly opposite with zones contiguous or partly overlapping that of acetabulum. Cirrus sac club-shaped, 0.14 to $0.21 \mathrm{~mm}$. long by 0.05 to $0.06 \mathrm{~mm}$. wide, lying entirely in front of or partly dorsal to anterior margin of acetabulum, containing convoluted seminal vesicle, prostatic gland cells, and eversible cirrus. Ovary round to transversely oval, 0.08 to $0.20 \mathrm{~mm}$. in long axis, situated to either right or left side of body, relatively close behind testis on ovarian side of body. Seminal receptacle globular, located dorsal to caudal margin of ovary. Mehlis' gland situated at posteromedial margin of seminal receptacle. Vitellaria composed of numerous medium-sized follicles, extending along lateral margins of body for a distance of 0.85 to $1.32 \mathrm{~mm}$., beginning within testicular zone and 

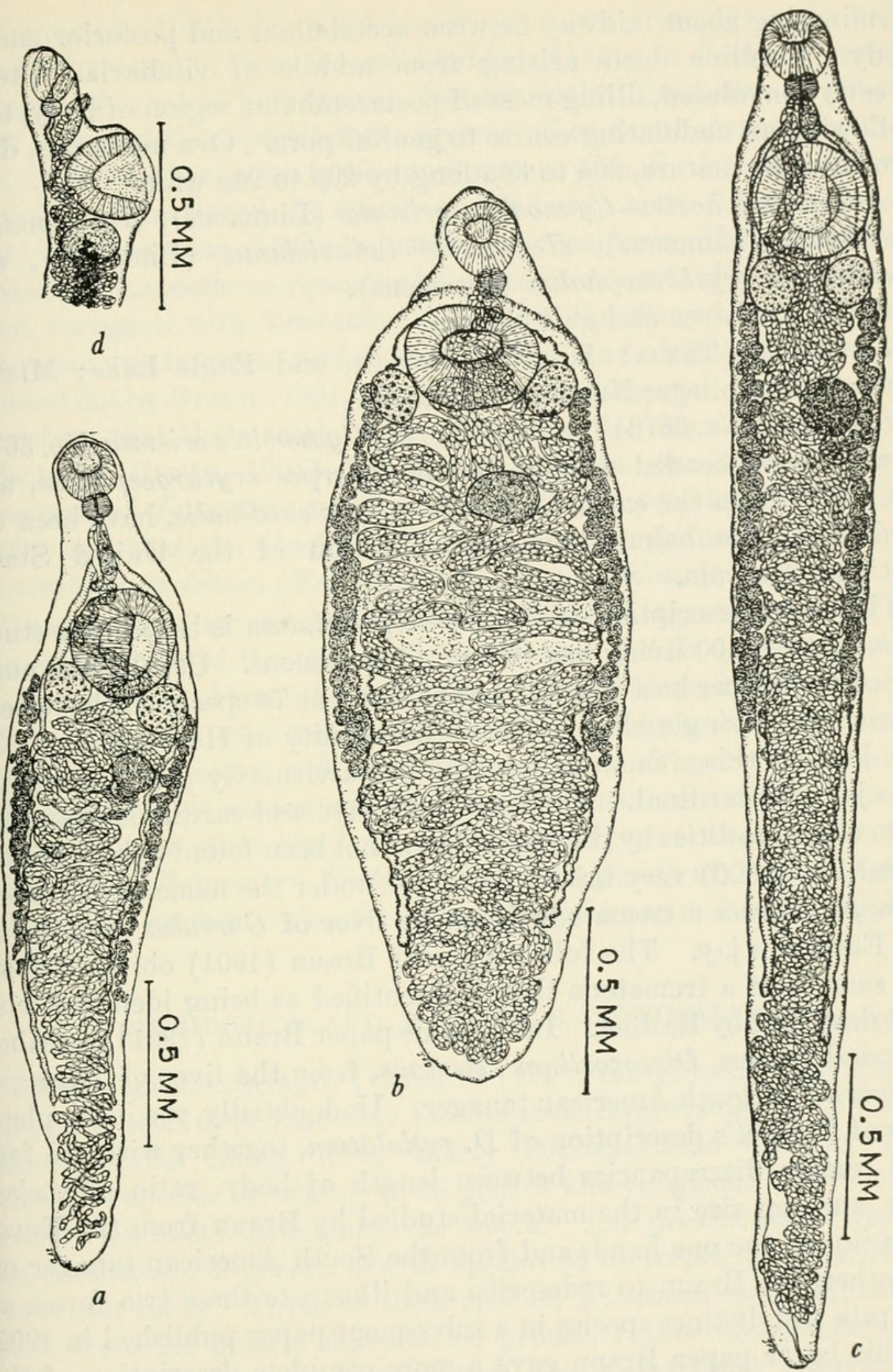

Figure 40.-a, Zonorchis petiolatum (Railliet, 1900), from the gall bladder of Cyanocitta cristata, ventral view, showing relative position of organs and shape of body in relaxed specimen; $b$, contracted specimen of Zonorchis petiolatum, from Cyanocitta cristata, showing a resemblance to species of the genus Platynosomum; $c$, extended specimen of Zonorchis petiolatum, from Cyanocitta cristata, showing a resemblance to certain species of the genus Lyperosomum; $d$, optical sagittal section of anterior end of Zonorchis petiolatum, from Cyanocitta cristata, showing relative position of organs and deep lumen of acetabulum. 
terminating about midway between acetabulum and posterior end of body. Vitelline ducts arising from middle of vitellaria. Uterus greatly convoluted, filling most of postacetabular region of body, then following an undulating course to genital pore. Ova numerous, dark brown when mature, $30 \mu$ to $36 \mu$ long by $20 \mu$ to $24 \mu$ wide.

Additional hosts.-Cyanocitta cristata (Linnaeus), Richmondena cardinalis (Linnaeus), Hedymeles ludovicianus (Linnaeus), and Melanerpes erythrocephalus (Linnaeus).

Habitat.-Liver and gall bladder.

Localities. Texas: Houston, Dewalt, and Eagle Lake; MissisSIPPI : State College; Nebraska : Lincoln.

Specimens No. 36734 from the blue jay Cyanocitta cristata, No. 36735 from the red-headed woodpecker, Melanerpes erythrocephalus, and No. 36736 from the cardinal, Richmondena cardinalis, have been deposited in the helminthological collection of the United States National Museum.

The above description of Zonorchis petiolatum is based on a study of more than 100 living and preserved specimens. Usually the number of worms per host is small, but as many as 75 specimens have been taken from a single blue jay from the vicinity of Houston, Tex. In this locality this trematode seems to be particularly prevalent in the blue jay and cardinal. Numerous blue jays and cardinals examined from other localities by the authors have not been found to be infected.

Railliet (1900) very briefly described under the name of Dicrocoelium petiolatum a trematode from the liver of Garrulus glandarius, the European jay. The following year Braun (1901) obtained from the same host a trematode that he identified as being identical with that described by Railliet. In the same paper Braun (1901) described a second species, Dicrocoelium delectans, from the liver of Thraupis palmarum, a South American tanager. Undoubtedly, the incompleteness of Railliet's description of $D$. petiolatum, together with the fact that certain discrepancies between length of body, ratio of sucker sizes, and egg size in the material studied by Braun from the European jay on the one hand, and from the South American tanager on the other, led Braun to redescribe and illustrate these two forms as separate and distinct species in a subsequent paper published in 1902. In this latter paper Braun gave a more complete description of the two forms and materially modified the discrepancies between the two forms as relating to ratio of suckers and size of the egg, thereby bringing these two forms into closer agreement. Braun, however, retained both forms as separate species.

Nicoll (1915) transferred Dicrocoetium petiolatum to the genus Platynosomum Looss, 1907, while Travassos (1916) considered $D$. delectans a member of this same genus. In 1944 Travassos transferred $D$. petiolatum to the genus Lyperosomum Looss, 1899. 
Travassos (1922) described under the name Platynosomum marquesi a dicrocoeliid from the gall bladder of the same South American tanager, Thraupis palmarum. Subsequently, Travassos (1944, p. 159) recorded this species from several other South American birds and declared his species to be synonymous with $D$. delectans Braun. Travassos transferred the species to his newly created genus Zonorchis. If Travassos (1944) is justified in considering the material included in his species marquesi to be synonymous with delectans Braun (and we agree with Travassos' decision), the disappearance of the discrepancies between petiolatum Railliet and delectans Braun as pointed out by Braun $(1901,1902)$ becomes apparent. It is suggested, therefore, that the material now grouped under the name Zonorchis delectans (Braun, 1901) Travassos, 1944, be considered a direct synonym of Lyperosomum (=Dicrocoelium) petiolatum (Railliet, 1900) and that the species be assigned to the genus Zonorchis, as Zonorchis petiolatum (Railliet, 1900), new combination.

The material in our collection is in perfect agreement with the present concept of the species Zonorchis petiolatum ( $=Z$. delectans of Travassos). From the material originally described by Railliet (D. petiolatum) our material differs in having a smaller body, a smaller sucker ratio, and smaller ova. From $D$. petiolatum as described by Braun our material differs only in having a slightly smaller body. On the other hand, our material conforms very closely with Zonorchis delectans (= Platynosomum marquesi) of Travassos with the possible exception that the cirrus pouch in our material is slightly smaller.

\section{DISTRIBUTION AND TAXONOMIC CONSIDERATIONS}

In a recent monograph, Travassos (1944) recognized 25 genera and subgenera with approximately 136 species as comprising the subfamily Dicrocoeliinae Looss, 1899, family Dicrocoeliidae Odhner, 1910. About 84 species belonging to 16 genera and subgenera are recorded from avian hosts throughout the world. The present paper reports the presence of 9 genera and 22 species of dicrocoeliids from North American birds. Three of these species, Athesmia wehri McIntosh, 1937, from the prairie sharp-tailed grouse, Pedioecetes phasianellus campestris, in Montana, Concinnum (= Eurytrema) hudovicianae (Petri, 1942) from the rose-breasted grosbeak, Hedymeles ludovicianus, in Nebraska, and Platynosomum (= Dicrocoelium) illiciens (Braun, 1901) from the broad-winged hawk, Buteo platypterus, in Ohio and Wisconsin, have not been studied by us. Of the remaining 19 species of dicrocoeliids from North American bird hosts 10 are described as new. The hosts, geographic distribution, and authority 
for the 22 species recorded from North American birds are given in table 1 .

Insofar as the over-all taxonomy of the Dicrocoeliinae is concerned it is here important only to point out certain duplication of taxonomic effort that has appeared in the literature within recent years. In studying a section of the subfamily, Bhalerao (1936) suggested that the then 17 valid species assigned to the genus Eurytrema Looss, 1907, showed characters sufficiently distinct for their separation into five subgenera. The names Pancreaticum, Concinnum, Conspicuum, and Skrjabinus in addition to Lubens, suggested by Travassos in 1920, were proposed for these five subgenera. For the characters on which this separation was made the reader is referred to Bhalerao's original paper.

Strom (1940), in working with dicrocoeliid trematodes from Eurasian hosts, accepted Bhalerao's division of the genus Eurytrema but elevated the subgenera Lubens, Conspicuum, Concinnum, and Skrjabinus to generic rank. He accepted the first three of these subgenera as defined by Bhalerao and retained the species as allocated in the original paper, although transferring a more recently described species, Eurytrema epomopis Sandground, 1937, to the genus Concinnum. After restudying the species Eurytrema skrjabinus Isiatschikoff, 1920, and E. koschewnikowi Skrjabin and Massino, 1925, the only two species included in the subgenus Skrjabinus by Bhalerao, Strom redefined the genus to include forms in which (1) the genital pore is ventral to or near the pharynx; (2) the vitellaria occupy the lateral margins of the body and extend from the region of the acetabulum (or behind this level) to a point considerably beyond the ovary; and (3) the uterus has numerous loops occupying the whole body posterior to the acetabulum. Strom described 5 new species, which he assigned to the genus Skrjabinus.

In the same paper, Strom (1940) proposed a revision of the genus Lyperosomum Looss, 1899, which now contained more than 50 species and subspecies. Three genera, Lyperosomum (sensu stricto), Brachylecithum, and Corrigia, were proposed for the reception of this assemblage of species. Lyperosomum longicauda (Rudolphi, 1809) was designated the type of the genus Lyperosomum, and the genus was restricted to those forms which showed (1) elongated bodies, the anterior end of which tapered more abruptly than did the posterior end; (2) subequal, muscular suckers, of which the acetabulum is the larger; (3) ceca ending in advance of the caudal extremity of the body; (4) testes oblique or symmetrical and close behind the acetabulum; (5) genital pore near the midline, at the posterior level of the pharynx; and (6) vitellaria consisting of numerous small follicles which extend from the zone of the testes to a level far short 
of the caudal extremity. Strom retained 12 species in the genus Lyperosomum.

In the second genus, Brachylecithum, Strom (1940) placed 25 species and 3 varieties formerly assigned to the genus Lyperosomum. The species filum (Dujardin, 1845) was designated as the type of the new genus. The generic group was briefly characterized as (1) possessing vitellaria composed of relatively few large follicles which occupied a small area just posterior to the ovary; (2) genital pore in the midline, ventral to the intestinal bifurcation; and (3) either one or two intestinal ceca which fail to reach the caudal end of the body. Brachylecithum (=Lyperosomum) filum was redescribed and figured. The species was represented as having branched intestinal ceca.

The third genus, Corrigia, proposed by Strom (1940) for species previously included in Lyperosomum, carried Corrigia (=Lyperosomum) corrigia (Braun, 1901) as the type. The group showed the following characters: (1) Body long and semitransparent; (2) weakly muscular suckers of approximately the same size; (3) two intestinal ceca which almost reach the caudal tip of the body; (4) genital pore ventral to or just posterior to the intestinal bifurcation; and (5) vitellaria consisting of numerous small follicles extending from the region of the ovary to a level behind the middle of the body. Four other species were assigned to the genus.

Travassos (1919) created the genus Oswaldoia for the reception of his species oswaldoi and transferred Dicrocoelium skrjabinus Solowiow, 1913, and Lyperosomum direptum Nicoll, 1914, to that genus. Since the erection of the genus several additional species have been described and assigned to Oswaldoia by various authors. Strom (1940) accepted Travassos' diagnosis of Oswaldoia and retained it as a valid genus for the species $O$. oswaldoi Travassos, 1919, O. marquesi (Travassos, 1922), O. petiolatum (Railliet, 1900), O. direptum (Nicoll, 1914), and O. pawlowskyi (Strom, 1928). Later, Travassos (1941b) erected the genus Lutztrema for the reception of those members of the genus Lyperosomum which possessed but a single cecum. In the genus, Travassos included the species formerly known as Lyperosomum obliquum Travassos, 1917, L. transversum Travassos, 1917, and $L$. monenteron Price and McIntosh, 1935, as well as three new species, L. marinholutzi, L. vermucosum, and $L$. insigne. On the basis of published figures alone Travassos provisionally includes several other species in his genus Lutatrema.

Being unaware of the paper published by Strom in 1940, Travassos (1944) elevated the subgenera Concinnum and Conspicuum of Bhalerao (1936) to generic rank. This writer, however, retained Lubens and Skrjabinus as subgenera of the genus Eurytrema. As defined by Travassos the genus Conspicuum is identical with the genus Skrjabinus as diagnosed by Strom. It is possible, therefore, to declare these 
two genera to be synonyms of each other. Since the name Conspicuum appears first in the original paper by Bhalerao, the proper designation of the genus is Conspicuum, and all species assigned to the genus Skrjabinus must be transferred to it.

Travassos (1944) recognized the unwieldiness of the assemblage of species assigned to the genus Lyperosomum Looss, 1899. Being unaware of the separation of the genus into three genera by Strom in 1940, Travassos proposed the genera Olssoniella and Orthorchis in addition to the genus Lyperosomum for the reception of this group of species. Travassos designated the species longicauda of Rudolphi, 1809, as the type of the genus Lyperosomum, and characterized the members of the genus in an almost identical way to that proposed by Strom. He further declared his genus Oswaldoia (1919) to be a direct synonym of Lyperosomum and transferred those species assigned to that genus to Lyperosomum. Sixteen species were listed as belonging to the genus.

For a second group of species formerly included in the genus Lyperosomum, Travassos (1944) erected the genus Olssoniella, with O. olssoni (Railliet, 1900) as the type. The genus Olssoniella is readily recognized as being identical with the genus Brachylecithum Strom, 1940. This identity is further evidenced by the fact that the species filum, the designated type of the genus Brachylecithum, is recognized as being congeneric with the species olssoni by its inclusion in the list of species given for the genus Olssoniella by Travassos. Travassos included 19 species in the genus Olssoniella. These species are hereby recognized as belonging to the genus Brachylecithum.

For the reception of a third group of species previously included in the genus Lyperosomum, Travassos (1944) erected the genus Orthorchis. Orthorchis (= Lyperosomum) lari (Travassos, 1917) was designated as the type, while six additional species were assigned to the genus. Among these species appears corrigia of Braun, 1901, the type species of the genus Corrigia as created by Strom, 1940. The quite similar diagnoses for the two genera (Corrigia and Orthorchis) together with the recognized congeneric relationship of the two type species renders the genus Orthorchis Travassos, 1944, a synonym of Corrigia Strom, 1940, and hence necessitates the transfer of the species included in the genus Orthorchis by Travassos to the genus Corrigia.

We have no hesitancy in restricting the genus Eurytrema to those species now allocated to that genus by Bhalerao, 1936, Strom, 1940, and Travassos, 1944. As emended by Strom, 1940, we recognize the genus Lubens Travassos, 1920. The genera Concinnum Bhalerao, 1936, as emended by Travassos, 1944, and Conspicuum (=Skrjabinus) Bhalerao, 1936, as emended by Strom, 1940, and Travassos, 1944, constitute valid generic groups. Furthermore, we recognize the genus 
Zonorchis Travassos, 1944, as a valid genus for the reception of certain species formerly included in the genera Eurytrema and Platynosomum, with the members of the genus Zonorchis differing from the remaining species of their respective generic groups in (1) the relatively large acetabulum in comparison to the size of the oral sucker; $(2)$ the more forward position of the genital pore; and (3) the extent and rounded rather than dendritic follicles of the vitellaria.

TABLE 1.-Distribution of dicrocoeliids in North American birds

\begin{tabular}{|c|c|c|c|}
\hline Host & TREMATODE & LOCALITY & REFERENCE \\
\hline Accipitridae: & & & \\
\hline Buteo lineatus & $\begin{array}{l}\text { Brachylecithum ameri- } \\
\text { canum. }\end{array}$ & Georgia... & This paper. \\
\hline Buteo platypterus & Platynosomum illiciens.... & Ohio; Wisconsin & $\begin{array}{l}\text { Denton and Rausch, } \\
1949 .\end{array}$ \\
\hline Tetraonidae: & & & \\
\hline $\begin{array}{l}\text { Pedioecetes phasia- } \\
\text { nellus campestris. }\end{array}$ & Athesmia wehri... & Montana_. & McIntosh, 1937. \\
\hline $\begin{array}{l}\text { Bonasa umbellus... } \\
\text { Gruidae: }\end{array}$ & Lutztrema monenteron(?).. & Minnesota. & Ishii, 1942. \\
\hline $\begin{array}{l}\text { Gruidae: } \\
\text { Grus canadensistabida. }\end{array}$ & Brachylecithum gruis. & Texas... & This naper \\
\hline Rallidae: & & HeAcos & 1110 paper. \\
\hline $\begin{array}{l}\text { Gallinula chloropus } \\
\text { cachinnans. } \\
\text { Strigidae: }\end{array}$ & Athesmia heterolecithodes... & Tennessee. & This paper. \\
\hline $\begin{array}{l}\text { Bubo virginianus...... } \\
\text { Picidae: }\end{array}$ & Brachylecithum moorei_.. & Texas (?) - & This paper. \\
\hline $\begin{array}{l}\text { Picidae: } \\
\text { Melanerpes erythro- } \\
\text { cephalus. } \\
\text { Tyrannidae: }\end{array}$ & Zonorchis petiolatum.. & Mississippi & This paper. \\
\hline $\begin{array}{l}\text { Tyrannus tyrannus... } \\
\text { Corvidae: }\end{array}$ & Lutztrema monenteron(?) & Minnesota ... & Ishii, 1942. \\
\hline & $\left(\begin{array}{l}\text { Lyperosomum oswaldoi.... } \\
\text { Lutztrema microstomum... }\end{array}\right.$ & $\begin{array}{l}\text { Texas. } \\
\text { North Carolina; Georgia; } \\
\text { Texas. }\end{array}$ & $\begin{array}{l}\text { This paper. } \\
\text { This paper. }\end{array}$ \\
\hline Cyanocitta cristata & $\begin{array}{l}\text { Brachylecithum america- } \\
\text { num. }\end{array}$ & Georgia. & Denton, 1945. \\
\hline & $\begin{array}{l}\text { Brachylecithum stunkardi.- } \\
\text { Zonorchis petiolatum }\end{array}$ & $\begin{array}{l}\text { Virginia; Texas.- } \\
\text { Texas. }\end{array}$ & $\begin{array}{l}\text { This paper. } \\
\text { This paper. }\end{array}$ \\
\hline Corvus brachyrhynchos & $\left\{\begin{array}{l}\text { Brachylecithum america- } \\
\text { num. }\end{array}\right.$ & Georgia............. & Denton, 1945. \\
\hline Mimidae: & Conspicuum macrorchis... & Tex & This paper. \\
\hline Mimus polyglottos.. & Lutztrema monenteron.... & Georgia; Texas & This paper. \\
\hline Toxostoma rufum & $\left\{\begin{array}{l}\text { Lyperosomum oswaldoi.... } \\
\text { Lutztrema monenteron..... }\end{array}\right.$ & $\begin{array}{l}\text { Georgia; } \text { Mississippi; } \\
\text { Texas. }\end{array}$ & $\begin{array}{l}\text { This paper. } \\
\text { This paper. }\end{array}$ \\
\hline Turdidae: & Brachylecithum exochocotyle & Georgia................. & This paper. \\
\hline & & $\begin{array}{l}\text { Virginia; Washington, } \\
\text { D. C.; Quebec, Cana- } \\
\text { da. }\end{array}$ & $\begin{array}{l}\text { Price and Mcintosh, } \\
1935 .\end{array}$ \\
\hline 1 utaus $m$ & Lutztrema monenteron. & $\begin{array}{l}\text { Virginia; North Caro- } \\
\text { lina; Georgia; Ohio; } \\
\text { Tennesee; Texas. }\end{array}$ & This paper. \\
\hline Sialia s & Lutztrema monenteron.. & Virginia & $\begin{array}{l}\text { Price and MeIntosh, } \\
1935 .\end{array}$ \\
\hline
\end{tabular}


TABLE 1.-Distribution of dicrocoeliids in North American birds-Continued

\begin{tabular}{|c|c|c|c|}
\hline Host & TREMATODE & LOCALITY & REFERENCE \\
\hline Parulidae: & & & \\
\hline Seiurus aurocapillus... & Brachylecithum seiuricum & Virginia... & This paper. \\
\hline Wilsonia canadensis... & $\begin{array}{l}\text { Brachylecithum tubercula- } \\
\text { tum. }\end{array}$ & Virginia.. & This paper. \\
\hline Icteridae: & & & \\
\hline $\begin{array}{l}\text { Sturnella magna argu- } \\
\text { tula. }\end{array}$ & $\left\{\begin{array}{l}\text { Brachylecithum america- } \\
\quad \text { num. } \\
\text { Conspicuum icteridorum..- }\end{array}\right.$ & Texas. & $\begin{array}{l}\text { Denton, } 1945 . \\
\text { This paper. }\end{array}$ \\
\hline Euphagus carolinus... & Conspicuum icteridorum... & Texas & This paper. \\
\hline $\begin{array}{l}\text { Cassidix mexicanus } \\
\text { major. }\end{array}$ & Conspicuum icteridorum & Texas.............. & This paper. \\
\hline $\begin{array}{l}\text { Cassidix mexicanus } \\
\text { prosopidicola. }\end{array}$ & $\left\{\begin{array}{l}\text { Brachylecithum america- } \\
\text { num. } \\
\text { Lubens lubens. } \\
\text { Conspicuum icteridorum... }\end{array}\right.$ & $\begin{array}{l}\text { Texas.............. } \\
\text { Texas. }\end{array}$ & $\begin{array}{l}\text { Denton, } 1945 . \\
\text { This paper. } \\
\text { This paper. }\end{array}$ \\
\hline $\begin{array}{l}\text { Ouiscalus quiscula } \\
\text { quiscula. }\end{array}$ & Conspicuum icteridorum & Georgia........... & This paper. \\
\hline $\begin{array}{l}\text { Ouiscalus quiscula } \\
\text { aeneus. }\end{array}$ & $\left\{\begin{array}{l}\text { Brachylecithum america- } \\
\text { num. } \\
\text { Conspicuum icteridorum... }\end{array}\right.$ & $\begin{array}{l}\text { Tennessee; Texas....... } \\
\text { Michigan; Tennessee; } \\
\text { Texas. }\end{array}$ & $\begin{array}{l}\text { Denton, } 1945 . \\
\text { This paper. }\end{array}$ \\
\hline $\begin{array}{l}\text { Thraupidae: } \\
\quad \text { Piranga olivacea }\end{array}$ & Lubens lubens.... & Virginia & This paper. \\
\hline $\begin{array}{l}\text { Fringillidae: } \\
\text { Richmondena cardina- } \\
\quad \text { lis. }\end{array}$ & Zonorchis petiolatum. & Texas... & This paper. \\
\hline $\begin{array}{l}\text { Hedymeles ludovicia- } \\
\text { nus. }\end{array}$ & 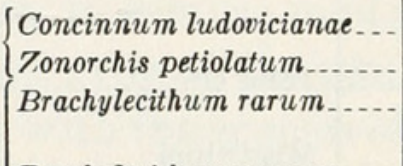 & $\begin{array}{l}\text { Nebraska } \\
\text { Vebraska } \\
\text { linginia; North Caro- }\end{array}$ & $\begin{array}{l}\text { Petri, } 1942 . \\
\text { This paper. } \\
\text { This paper. }\end{array}$ \\
\hline $\begin{array}{l}\text { Pipilo erythrophthal- } \\
\text { mus. }\end{array}$ & $\left\{\begin{array}{l}\text { Brachylecithum nanum.... } \\
\text { Brachylecithum delicatum.. } \\
\text { Zonorchis alveyi }\end{array}\right.$ & $\begin{array}{l}\text { Virginia; North Caro- } \\
\text { lina. } \\
\text { North Carolina } \\
\text { Virginia; North Caro- } \\
\text { lina; Georgia. }\end{array}$ & $\begin{array}{l}\text { This paper. } \\
\text { This paper. } \\
\text { This paper. }\end{array}$ \\
\hline Junco hyemalis ......... & Zonorchis alveyi & Indiana .......... & Martin and Gee, 1949. \\
\hline Zonotrichia leucophrys. & Zonorchis alveyi & Georgia.......... & This paper. \\
\hline Zonotrichia albicollis & $\left\{\begin{array}{l}\text { Brachylecithum nanum.... } \\
\text { Zonorchis alveyi }\end{array}\right.$ & $\begin{array}{l}\text { Georgia; Texas.... } \\
\text { Texas }\end{array}$ & $\begin{array}{l}\text { This paper. } \\
\text { This paper. }\end{array}$ \\
\hline Melospiza georgiana... & Zonorchis alveyi & Georgia.... & This paper. \\
\hline Melospiza melodia & Zonorchis alveyi & Georgia & This paper. \\
\hline
\end{tabular}

\section{LITERATURE CITED}

Bhalerao, C. D.

1936. Studies on the helminths of India: Trematoda, I. Journ. Helminthology, vol. 14, pp. 163-180.

Braun, M.

1899. Ein neues Distomum aus Porphyrio. Zool. Anz., vol. 22, pp. 1-4.

1901. Zur Revision der Trematoden der Vögel, I, II. Centralbl. Bakt. Parasit., vol. 29, pp. 560-568, 895-897, 941-948.

1902. Fascioliden der Vögel. Zool. Jahrb., Abt. Syst., vol. 16, pp. 1-162. Denton, J. F.

1945. Studies on the life history of Brachylecithum americanum $\mathbf{n}$. sp., a liver fluke of passerine birds. Journ. Parasit., vol. 31, pp. 131-141. 


\section{Denton, J. F., and RaUsch, R.}

1949. The occurrence of Platynosomum illiciens (Braun, 1901) in a North American hawk. Proc. Helminth. Soc. Washington, vol. 16, pp. 7-9. GoMes de Faria.

1912. Beiträge zur Systematik der brasilianischen Helminthin. V. Dicrocoelium conspicuum n. sp., ein Parasit der Gallenblase von Mimus lividus. Mem. Inst. Oswaldo Cruz, vol. 4, pp. 62-65, pl. 1.

ISAICHIKOV, I. M.

1920. Uber einem neuen Vertreter der Gattung Eurytrema Looss. Izvest. Donsk. Vet. Inst., Novotscherkassk, vol. 1, pp. 1-11.

\section{IsHII, N.}

1942. New parasite records from the ruffed grouse. Journ. Parasitol., vol. 28, p. 92 .

JACOBY, S.

1899a. Mittheilungen über Distomum heterolecithodes Braun. Zool. Anz., vol. 22 , pp. 133-135.

1899b. Beiträge zur Kenntniss einiger Distomen. Arch. Naturg., for 1900, vol. 1, pp. 1-30.

JoHNston, S. J.

1917. On the trematodes of Australian birds. Proc. Roy. Soc. New South Wales, vol. 50, pp. 187-261, figs. 1-10, pls. 9-19.

\section{LAYMAN, E. M.}

1922. Zur Charakteristik neuer Lyperosomum-Arten. Centralbl. Bakteriol., vol. 56, pp. 568-572, figs. 1-3.

1926. Trematodes of the bile ducts of Russian birds. Trav. Lab. Parasit. Univ. Et. Moscow, pp. 59-72.

Looss, A.

1899. Weitere Beiträge zur Kenntniss der Trematodenfauna Aegyptens. Zool. Jahrb., Abt. Syst., vol. 12, pp. 521-784.

1907a. Some parasites in the museum of the School of Tropical Medicine, Liverpool. Ann. Trop. Med. Parasit., vol. 1, pp. 121-154.

1907b. Ueber einige zum Teil neue Distomen der europäischen Fauna. Centralbl. Bakt. Parasitol., vol. 43, pp. 604-613.

Martin, W. E., and Gee, D.

1949. A new species of Eurytrema (Trematoda: Dicrocoellidae) from the slate-colored junco. Journ. Parasitol., vol. 35, pp. 61-66.

McIntosh, A.

1937. Two new avian liver flukes with a key to the species of the genus Athesmia Looss, 1899 (Dicrocoeliidae). Proc. Helminth. Soc. Washington, vol. 4, pp. 21-23.

NicolL, W.

1914. Trematode parasites from animals dying in the Zoological Society's gardens during 1911-1912. Proc. Zool. Soc. London, 1914, pp. 139-154.

1915. A new liver fluke (Platynosomum acuminatum) from the kestrel. Proc. Zool. Soc. London, 1915, pp. 87-89, fig. 1.

Pande, B. P.

1939. On the trematode genus Lyperosomum Looss, 1899 (Dicrocoeliidae) with a description of two new species. Proc. Nat. Acad. Sci. India, vol. 9, pp. 15-21. 
Petri, L. H.

1942. Two new dicrocoeliid trematodes from birds. Trans. Amer. Micr. Soc., vol. 61, pp. 57-61, 1 pl.

Price, E. W., and McIntosh, A.

1935. A new trematode, Lyperosomum momenteron n. sp. (Dicrocoeliidae), from a robin. Proc. Heiminth. Soc. Washington, vol. 2, pp. 63-64, fig. 12 .

Ratlliet, A.

1900. Trématodes hépatiques des oiseaux. Compt. Rend. Soc. Biol., vol. 52 , pp. 239-242.

SANDGround, J. H.

1929. A new liver fluke from a monkey and new parasitic round-worms from various African animals. Proc. U. S. Nat. Mus., vol. 75, art. 12 , pp. $1-11,2$ pls.

SkrJabIN, K. I.

1913. Vogeltrematoden aus Russich Turkestan. Zool. Jahrb., Abt. Syst., vol. 35, pp. 351-388.

SkrJabin, K. I., and Massino, B. G.

1925. Trematoden bei den Vögeln des Moskauer Gouvernements. Centralbl. Bakt. Parasit., vol. 64, pp. 453-462.

Solowiow, P. T.

1911. Eine neue Art des Genus Dicrocoelium Dujardin und eine Excursion in Gebeit der Systematik Phylogenie der Fascoelidae der Vögel. Arb. Zool. Lab. Univ. Warschan, pp. 1-23.

Sтrом, J.

1928. Eine neue Art der Vogeltrematoden Oswaldoia pawlowskyi n. sp. Zool. Anz., vol. 77, pp. 184-189, fig. 1.

1940. Notes on the classification of the Dicrocoelinae (Trematoda). Parasitol. Sborn Zool. Inst. Akad. Nauk U.S.S.R., vol. 8, pp. 176-188.

Travassos, L.

1916. Trematodeos novos. Brazil-Medico, vol. 30, pp. 257-258.

1917. Especies brazileiras do genero Lyperosomum. First Conf. Soc. Sud.Amer. Hig., 1916, pp. 737-745, figs. 1-6.

1920. Contribuição para a sistematica dos Dicrocoelinae Looss, 1899. Arch. Esc. Sup. Agr. e Med. Vet. Nictheroy, vol. 3 (1919), pp. 7-24.

1922. Informações sobre a fauna helminthologica de Matta Grosso. Folha Med., vol. 3, pp. 187-190.

1941a. Eurytrema ellipticum n. sp. (Trematoda, Dicrocoeliidae). Rev. Bras. Biol., vol. 1, pp. 201-202.

1941b. Lutztrema n. g. (Trematoda; Dicrocoeliidae). Mem. Inst. Oswaldo Cruz, vol. 36 , pp. 335-343.

1944. Revisão da família Dicrocoeliidae Odhner, 1910. Monogr. Inst. Oswaldo Cruz, No. 2, pp. 1-357.

YAMAGUTI, S.

1939. Studies on the helminth fauna of Japan, pt. 25: Trematodes of birds, IV. Jap. Journ. Zool., vol. 8, pp. 129-210.

1941. Studies on the helminth fauna of Japan, pt. 32: Trematodes of birds, V. Jap. Journ. Zool., vol. 9, pp. 321-341. 


\section{$2 \mathrm{BHL}$ Biodiversity Heritage Library}

1951. "The helminth parasites of birds. III. Dicrocoeliid trematodes from

North American birds." Proceedings of the United States National Museum 101, 157-202.

View This Item Online: https://www.biodiversitylibrary.org/item/31795

Permalink: https://www.biodiversitylibrary.org/partpdf/30774

\section{Holding Institution}

Smithsonian Libraries

\section{Sponsored by}

Smithsonian

\section{Copyright \& Reuse}

Copyright Status: NOT_IN_COPYRIGHT

Rights: https://www.biodiversitylibrary.org/permissions/

This document was created from content at the Biodiversity Heritage Library, the world's largest open access digital library for biodiversity literature and archives. Visit BHL at https://www.biodiversitylibrary.org. 